\title{
NOVOS DADOS GEOCRONOLÓGICOS U-PB DE ZIRCÕES DETRÍTICOS NA SERRA DO ESPINHAÇO MERIDIONAL, REGIÕES DE ALTAMIRA E IPOEMA
}

\author{
NEW U-PB GEOCHRONOLOGICAL DATA OF DETRITAL ZIRCONS ON THE SOUTHERN \\ ESPINHAÇO RANGE, REGIONS OF ALTAMIRA AND IPOEMA
}

\author{
Luciano Bruno Elpidio da Rocha OLIVEIRA ${ }^{1}$, Carlos Alberto ROSIÈRE ${ }^{2}$, Vassily Khoury \\ ROLIM $^{3}$, João Orestes Schneider SANTOS ${ }^{4}$ \\ ${ }^{1}$ Universidade Federal de Minas Gerais, Programa de Pós-Graduação em Geologia Regional. Av. Pres. Antônio Carlos, 6627 - Pampulha, \\ Belo Horizonte - MG. Email: oreblu@gmail.com \\ ${ }^{2}$ Universidade Federal de Minas Gerais. Av. Pres. Antônio Carlos, 6627 - Pampulha, Belo Horizonte - MG. \\ Email: crosiere@gmail.com \\ ${ }^{3}$ PRCZ Consultores Associados. R Aristoteles Caldeira, 852, Alto Barroca, Belo Horizonte, MG. Email: vassily.rolim@gmail.com \\ ${ }^{4}$ University of Western Australia. 35 Stirling Hwy, Crawley WA 6009, Perth Austrália. Email: orestes.santos@ bigpond.com
}

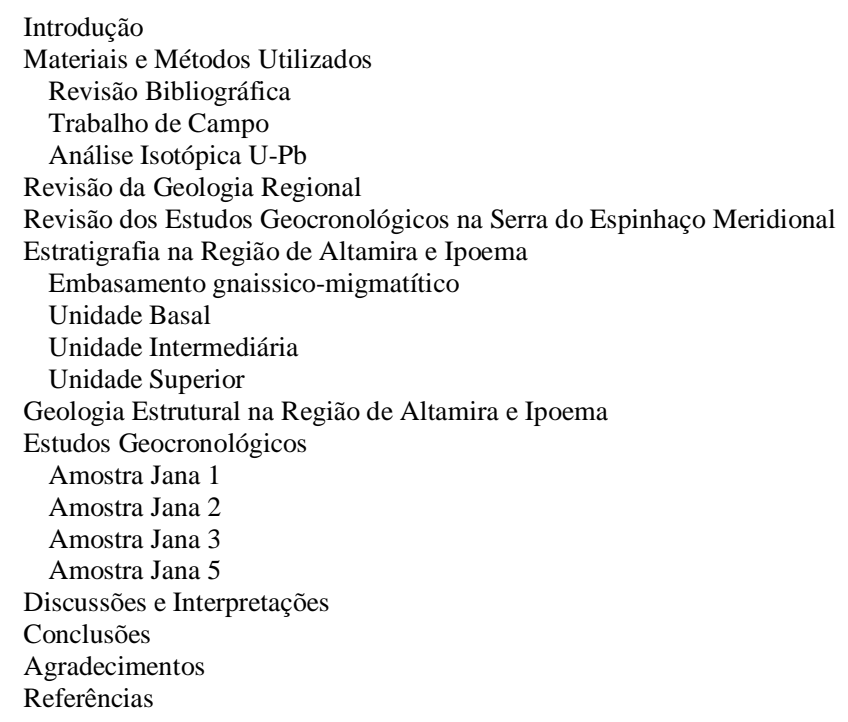

RESUMO - A Serra do Espinhaço Meridional é representada principalmente pelas unidades do Supergrupo Espinhaço formado por um espesso pacote de quartzitos, filitos e metaconglomerados, com metavulcânicas, formações ferríferas bandadas e carbonatos subordinados. As rochas metassedimentares da região de Altamira e Ipoema foram divididas em três unidades litoestratigráficas: a Unidade Basal constituída por metaconglomerado e quartzito, a Unidade Intermediária constituída por quartzito com metaconglomerados e filitos associados e a Unidade Superior constituída por quartzitos com estratificação cruzada de grande porte. A área estudada foi dividida em dois domínios estruturais: Oeste, onde as rochas estão dobradas formando sinclinais e anticlinais em escala macroscópica e Leste, onde prevalece uma tectônica de cavalgamentos frontais formando cavalos tectônicos de direção aproximada N-S vergentes para oeste. A deposição sedimentar nesta região iniciou ao final do Paleoproterozoico no período Estateriano, com idade máxima de deposição dos sedimentos em $1.751 \pm 19$ Ma. A distribuição das idades indica um preenchimento da bacia nesta região por aporte de fontes mais antigas predominantemente autóctones localizadas a norte e oeste da bacia, sendo a maioria relacionada a terrenos de idade riaciana/orosiriana, seguido pelos mesoarqueanos/neoarqueanos e estaterianos, com pequena contribuição alóctone relacionada a terrenos de idade sideriana e paleoarqueana.

Palavras-Chave: Geocronologia U-Pb, Estateriano, Serra do Espinhaço Meridional, zircões detríticos.

ABSTRACT - The Southern Espinhaço Range is mainly represented by the units of the Espinhaço Supergroup which comprises a thick sequence of quartzites, phyllites and metaconglomerates with metavolcanic rocks, banded iron formations and limestones subordinate. The metasedimentary rocks of the Altamira and Ipoema regions were divided into three lithostratigraphic units: Basal Unit composed of metaconglomerate and quartzite, Intermediary Unit composed of quartzite with metaconglomerate and phyllites associated and the Upper Unit composed of quartzites with large cross-stratification. The studied area was divided into two structural domains: West, where the rocks are folded forming synclines and anticlines on a macroscopic scale and East where a tectonics of frontal horses prevails forming tectonic horses of approximate direction N-S with vergence towards the west. Sedimentary deposition in this region began at the end of the Paleoproterozoic, Statherian period, with maximum sediment deposition age at $1.751 \pm 19 \mathrm{Ma}$. The age distribution indicates a basin filling in this region by the contribution of older, predominantly autochthonus sources located to the north and west of the basin, most of which are related to lands of the Rhyacian/Orosirian ages, followed by the Mesoarchean/Neoarchean and Statherian lands, with a small allochthonous contribution related to lands of Siderian and Paleoarchean ages.

Keywords: U-Pb Geochronology, Statherian, Southern Espinhaço Range, detrital zircons. 


\section{INTRODUÇÃO}

O empilhamento estratigráfico da Serra do Espinhaço Meridional é estudado e discutido por vários pesquisadores há quase dois séculos. Apesar das várias pesquisas e trabalhos de cartografia geológica realizadas em diferentes regiões da serra, uma série de questionamentos ainda se encontram em discussão, sendo um deles, qual unidade metassedimentar marca o início da sedimentação da bacia Espinhaço e qual seria sua idade. Outra questão é a correlação do empilhamento estratigráfico próximo à região de Diamantina (Porção Central) e próximo das regiões de Serro/
Conceição do Mato Dentro (Borda Leste) com áreas mais distantes da Serra do Espinhaço Meridional. Esta correlação é dificultada devido à ausência e/ou escassez de dados geológicos em algumas regiões.

A área investigada se enquadra neste contexto. Ela está localizada na extremidade sul da Serra do Espinhaço Meridional na região central do Estado de Minas Gerais, próximo aos distritos de Altamira e Ipoema, a nordeste da capital Belo Horizonte (Figura 1), onde o acervo de informações a respeito da estratigrafia é limitado e em relação à geocronologia é inexistente.

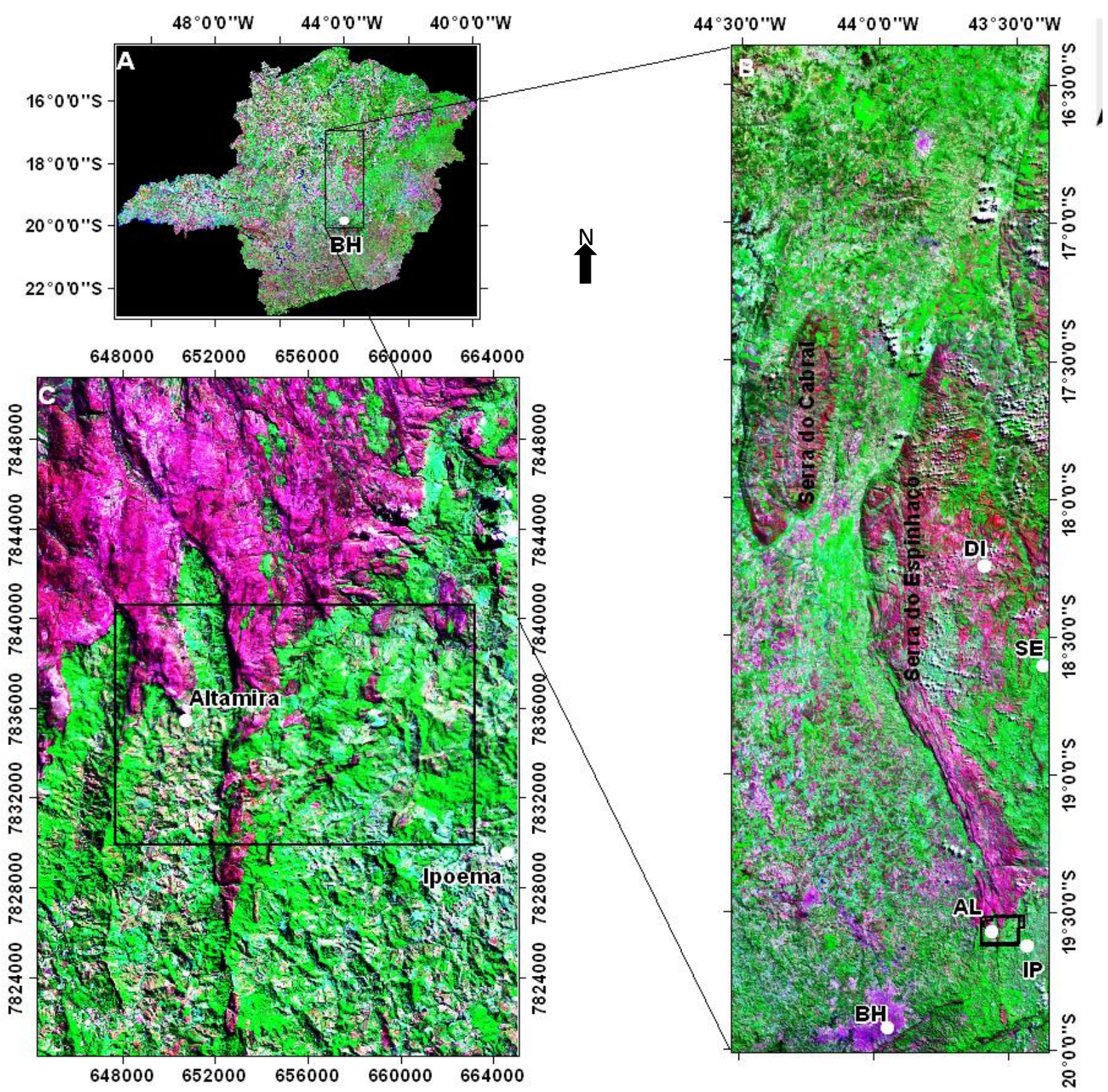

Figura 1 - Carta imagem mostrando a localização da área investigada na Serra do Espinhaço Meridional (Fonte: Embrapa Monitoramento por Satélite - imagens Landsat 5 e 7). Localidades: BH - Belo Horizonte, AL - Altamira, IP - Ipoema, SE - Serro, DI - Diamantina. $\square$ Área investigada.

As poucas informações geológicas existentes nesta região estão relacionadas a três trabalhos, onde apenas dois deles correlacionam as unidades metassedimentares das regiões de 
Altamira e Ipoema com as rochas do Supergrupo Espinhaço. Sperber (1977) publicou sua tese de doutorado intitulada "Geologia do Precambriano no Sudoeste da Serra do Cipó (Serra do Espinhaço, Minas Gerais, Brasil)" - Geologie des Präkambrius am Südwestrand der Serra do Cipo (Serra do Espinhaço, Minas Gerais, Brasilien). Este foi o estudo pioneiro na região.

Posteriormente, Brandalise \& Heineck (1999) produziram um mapa geológico, na escala 1:100.000, da Folha Belo Horizonte e Padilha et al. (2000) produziram um mapa geológico, na escala 1:100.000, da Folha Itabira. Estes dois trabalhos correlacionaram as rochas metassedimentares das regiões de Altamira e Ipoema com o Supergrupo Espinhaço, atribuindo-as às formações Sopa-Brumadinho e Galho do Miguel, definidas por Pflug (1968).

Este trabalho tem como objetivo contribuir para o entendimento da geologia da região investigada com a definição da unidade metassedimentar basal e sua idade de deposição, auxiliado por estudos geocronológicos de zircões detríticos. Com isso, tentar estabelecer uma correlação cronoestratigráfica desta região com o contexto geológico da Serra do Espinhaço Meridional tanto em relação à sua porção central como em relação à borda leste.

\section{MATERIAIS E MÉTODOS UTILIZADOS}

\section{Revisão Bibliográfica}

Foi realizado um levantamento de dados geológicos referentes a Serra do Espinhaço Meridional disponíveis na literatura como artigos publicados em periódicos e anais de congressos e simpósios, dissertações e teses, principalmente aqueles relacionados às unidades consideradas basais, com ênfase nos dados estratigráficos e geocronológicos.

\section{Trabalhos De Campo}

Para a definição da unidade metassedimentar basal na área estudada foram realizados trabalhos de campo com caminhamentos, perfis estratigráficos e visitas a pontos específicos da área, principalmente aqueles interpretados previamente pelos autores (imagem do Google Earth) como sendo contato entre unidades.

\section{Análise Isotópica U-Pb}

Para estes estudos foram coletadas cinco amostras de quartzito pertencente à mesma unidade estratigráfica denominada de Unidade Basal (posição estratigráfica determinada pelo mapeamento geológico), com aproximadamente $20 \mathrm{~kg}$ cada, onde quatro delas foram coletadas ao longo de um mesmo perfil geológico regional, visando uma interpretação mais robusta dos dados. Após a separação dos zircões, foi constatado que os zircões de uma das amostras (Jana 4) não tinham boa qualidade para análise devido ao intenso fraturamento dos grãos e a grande quantidade de inclusões. Sendo assim, somente quatro das amostras foram analisadas.

A preparação das amostras foi realizada no Laboratório de Preparação de Amostras Geológicas e Pedológicas (LAGEPE) da Universidade Estadual Paulista (UNESP), em Rio Claro Estado de São Paulo (britagem, moagem, peneiramento, bateamento, secagem de concentrado, separação por líquido denso e secagem de minerais mais densos que $o$ bromofórmio). Duas das amostras tiveram parte do processo de preparação (separação por líquido denso e secagem de minerais mais densos que o bromofórmio), realizado no Centro de Desenvolvimento da Tecnologia Nuclear (CDTN) localizado no campus da Universidade Federal de Minas Gerais (UFMG). O processo de separação magnética foi realizado no Laboratório de Minerais Pesados no Instituto de Geociências da Universidade Federal de Minas Gerais.

O procedimento de preparação das amostras para separação dos zircões compreendeu, em ordem, as seguintes etapas (Figura 2):

Britagem - cada amostra passou por dois britadores de mandíbula. $\mathrm{O}$ primeiro foi um britador FURLAN, modelo BM 2010, 7.5 C.V. e 380 RPM. O segundo foi um britador RETSCH, TYP BB1/A, de menor tamanho (Figura 2A).

Moagem - após serem britadas, as amostras foram pulverizadas em um moinho a rolos FURLAN, tipo MR 2013, 350 RPM com motor de indução trifásico (Figura 2B).

Peneiramento - depois da moagem foi utilizado uma peneiradora vibratória (Figura 2C) com peneira de malha $300 \mu \mathrm{m}$. A peneira foi agitada durante 20 minutos separando a fração fina da fração média/grossa.

Bateamento - foi realizado utilizando uma bateia mecanizada (Figura 2D). Sua inclinação é ajustável e neste caso o ângulo usado foi de $60^{\circ} \mathrm{em}$ relação a horizontal. Enquanto a bateia gira automaticamente a uma velocidade constante, um cano em sua porção central, na posição horizontal, fornece água para o procedimento. $\mathrm{O}$ material 
peneirado é colocado aos poucos na base da bateia. Sua parte interna possui calhas em um formato espiral que converge para o centro da bateia, onde há um orifício por onde são captados os minerais pesados concentrados pelo procedi-mento, que são coletados em uma peneira de malha $0,053 \mathrm{~mm}$ na parte posterior da bateia (Figura 2E).

Secagem do concentrado - o concentrado de cada amostra, produto do bateamento, foi secado totalmente em "caixas de luz" (Figura 2F).

Separação por líquido denso (Bromofórmio) totalmente secos, os concentrados foram colocados em líquido denso, bromofórmio $\left(\mathrm{CHBr}_{3}\right)$, para separação dos minerais mais densos que o líquido, dentre eles os zircões. O bromofórmio é um reagente analítico tóxico e muito volátil, sendo necessário o manuseio em condições adequadas. Sendo assim, o procedimento foi realizado em capela com exaustão forçada (Figura 2G) utilizando luvas de borracha, óculos de proteção e máscara com filtro de ar. O bromofórmio é colocado em um filtro, onde em seguida o concentrado é adicionado e misturado para homogeneizar a solução. Feito isto, espera-se durante alguns minutos a decantação dos minerais mais densos que o líquido.

Os minerais de menor densidade que o bromofórmio fica em suspensão. Finalizada a decantação, a torneira é aberta deixando sair somente os minerais mais pesados, que serão coletados em um funil recoberto por filtro de papel, dentro de um becker que coletará o bromofórmio. $\mathrm{O}$ mesmo se faz com os minerais mais leves (suspensos). Depois, os materiais coletados no filtro de papel são "lavados" com álcool etílico hidratado ( $93,8^{\circ}$ INPM).
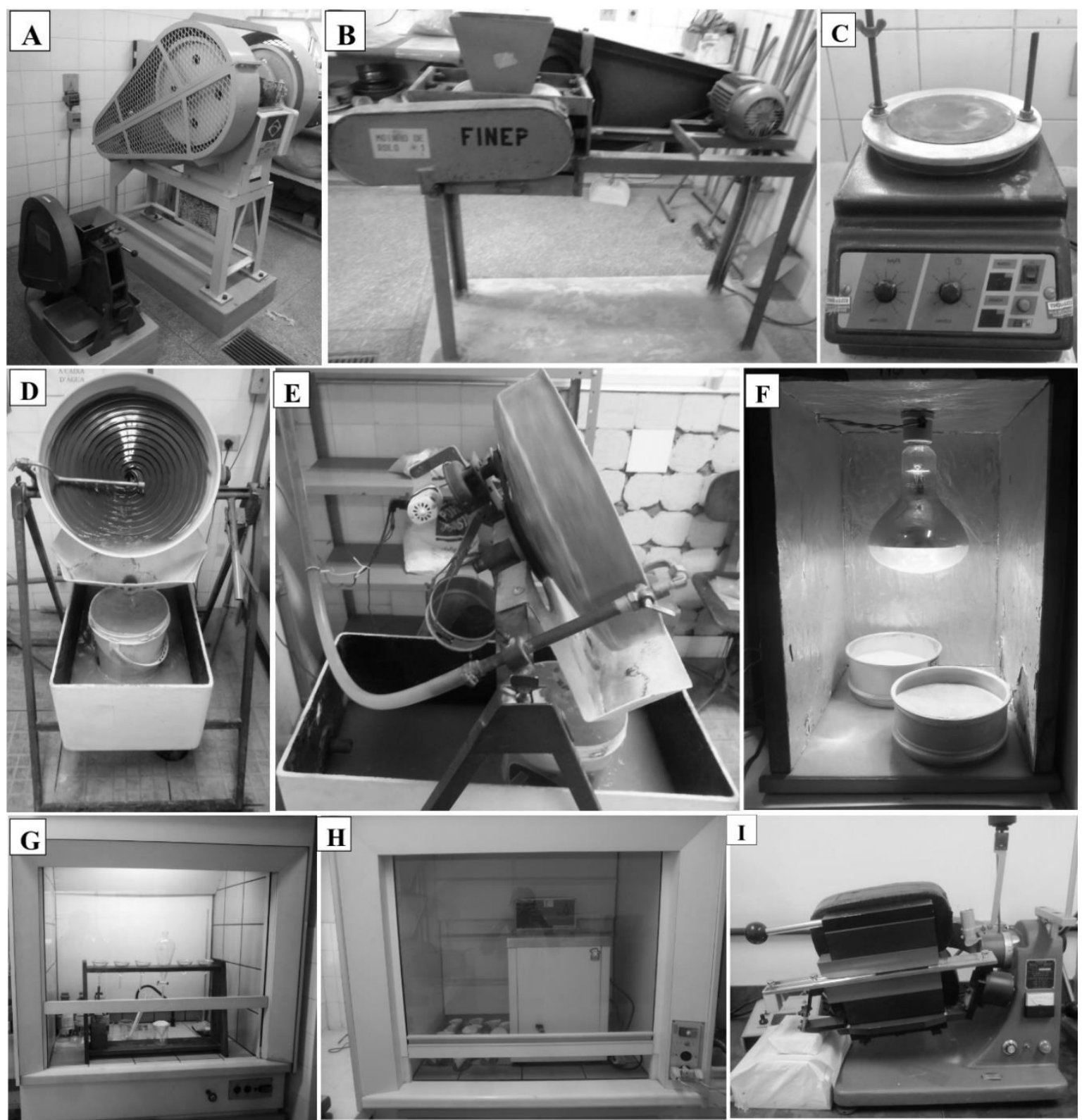

Figura 2 - Equipamentos utilizados na preparação dos zircões para as análises isotópicas U-Pb. Para descrição dos itens, ver texto. 
Secagem de minerais mais densos que o bromofórmio - após a separação, o filtro de papel com os minerais pesados é colocado em um exaustor para sua secagem completa (Figura $2 \mathrm{H}$ ).

Separação magnética - após estarem secos, os minerais mais pesados que o líquido denso, foram separados com uso de um separador magnético Frantz LB1 (Figura 2I) que é composto, de maneira simplificada, por uma calha vibratória localizada entre dois eletroímãs de corrente regulável que definem a intensidade do campo magnético. Cada amostra foi submetida a diferentes intensidades de amperagem, variando de 0,1 até 1,5 A, sendo que de 0,1 até $0,5 \mathrm{~A}$, a intensidade foi aumentada de 0,1 em 0,1 A. De 0,5 até 1,5 A, a intensidade foi aumentada de 0,2 em 0,2 A. A calha por onde os minerais passaram tinha uma inclinação de $10^{\circ}$.

Os equipamentos pertencem ao Laboratório de Preparação de Amostras Geológicas e Pedológicas (LAGEPE) da Universidade Estadual Paulista (Figura 2A até $2 \mathrm{H}$ ) e ao Laboratório de Minerais Pesados no Instituto de Geociências da Universidade Federal de Minas Gerais (Figura 2I)

Seleção ótica dos grãos - a porção dos minerais não magnéticos de cada amostra, separados no Frantz, foi analisada em lupa binocular onde os grãos de zircão foram selecionados manualmente, por catação.

Estes zircões foram acondicionados em pequenos recipientes de plástico e devidamente identificados.

Os zircões selecionados foram enviados para a University of Western Austrália onde foram selecionados no Centre for Microscopy, Characterisation and Analysis.

No laboratório, foram montados em um único disco de epoxi com $2,5 \mathrm{~cm}$ de diâmetro (mount). $\mathrm{O}$ mount foi polido usando papéis-lixa de grão 800 , $1.200,2.000$ e 4.000. Foi feito um polimento final com pó de diamantes com granulometria de $1 \mu \mathrm{m}$ e $1 / 4 \mu \mathrm{m}$. Após o polimento a montagem foi recoberta com carbono para imageamento por retroespalhamento de elétrons (Back-Scattered Electrons Imaging - BSE) usando um microscópio eletrônico de varredura (MEV) JOS-N1741 acoplado a um espectrômetro de dispersão de energia (Energy Dispersive Spectrometer - EDS). As imagens geradas permitiram a compreensão da estrutura interna dos grãos de zircão, e consequentemente, a seleção das melhores áreas para colocação dos pontos de análises, evitando-se as áreas metamíticas, fraturadas e as inclusões. Também permitiu mostrar as variações da morfologia dos grãos e feições internas evidenciando a natureza detrítica.

As análises de $\mathrm{U}-\mathrm{Pb}$ nos zircões foram feitas com o uso de uma sonda eletrônica de alta resolução (Sensitive High-mass Resolution Ion MicroProbe - SHRIMP II) localizada na Curtin University of Technology em Perth, Austrália. As análises foram realizadas usando um feixe primário de 2,10 a $3,55 \mu \mathrm{A}$ focado em pontos com 20 a 25 $\mu \mathrm{m}$. Amostras padrão de idade U-Pb de $561,3 \mathrm{Ma}$ e $840 \mathrm{ppm} \mathrm{U}$, foram usadas para monitorar a razão ${ }^{207} \mathrm{~Pb} /{ }^{206} \mathrm{~Pb}$ e para calibrar o conteúdo de urânio. As análises foram compostas por 4 escaneamentos e cada um deles foi formado por 9 picos. Os erros das idades individuais foram calculados no intervalo de 1 desvio-padrão $(1 \sigma)$ enquanto as idades nos gráficos foram calculadas para 2 desvio-padrão $(2 \sigma)$, ou seja, com $95 \%$ de confiança.

Razões isotópicas ${ }^{207} \mathrm{~Pb} /{ }^{206} \mathrm{~Pb}, \quad{ }^{207} \mathrm{~Pb} /{ }^{235} \mathrm{U}$, ${ }^{206} \mathrm{~Pb} /{ }^{238} \mathrm{U}$ e ${ }^{208} \mathrm{~Pb} /{ }^{232} \mathrm{Th}$, assim como as idades ${ }^{206} \mathrm{~Pb} /{ }^{238} \mathrm{U}$ e ${ }^{207} \mathrm{~Pb} /{ }^{206} \mathrm{~Pb}$, foram calculadas pelo software SQUID ${ }^{\circledR} 2.50$ (Ludwig 2009). O gráfico de probabilidade foi preparado pelo software ISOPLOT/Ex ${ }^{\circledR} 3.00$ (Ludwig 2003), utilizando as idades ${ }^{207} \mathrm{~Pb} /{ }^{206} \mathrm{~Pb}$.

\section{REVISÃO DA GEOLOGIA REGIONAL}

A Serra do Espinhaço Meridional é representada principalmente pelas unidades do Supergrupo Espinhaço que compreende um conjunto de rochas metassedimentares constituída principalmente de quartzitos, metapelitos e metaconglomerados, com metavulcânicas, formações ferríferas bandadas e carbonatos subordinados (Figura 3). Estas rochas metassedimentares estão sobrepostas a um complexo ígneo predominantemente granítico e granodiorítico com migmatitos associados, de idade arqueana de $2,8 \mathrm{Ga}$ (Machado et al., 1989) que foi retrabalhado durante a orogênese paleoproterozoica entre 2,2 e 2,0 Ga (Danderfer et al., 2009). Pflug (1968) elaborou uma coluna litoestratigráfica dividindo este espesso conjunto de rochas metassedimentares em oito formações, sendo a Formação São João da Chapada a unidade basal desta coluna, que serve ainda hoje como referência para os estudos na Serra do Espinhaço Meridional.

Schöll \& Fogaça (1979), Fogaça et al. (1984), Dossin et al. (1985) e Knauer (1990, 2007) mantém esta unidade como sendo o primeiro registro 
sedimentar da bacia Espinhaço em sua porção central (região de Diamantina), mas AlmeidaAbreu (1993), Almeida-Abreu \& Pflug (1994), Silva (1998), Martins-Neto (1998, 2000), Chemale Jr et al. (2012), Santos et al. (2013) e Rodrigues da Silva (2016) consideram a Formação Bandeirinha, definida por Fogaça et al.
(1984) como sendo uma unidade metassedimentar pertencente ao topo do Supergrupo Rio Paraúna, a unidade metassedimentar basal do registro estratigráfico da bacia Espinhaço na porção central. Estes autores agregam esta formação ao Grupo Guinda, definido por Knauer (1990).

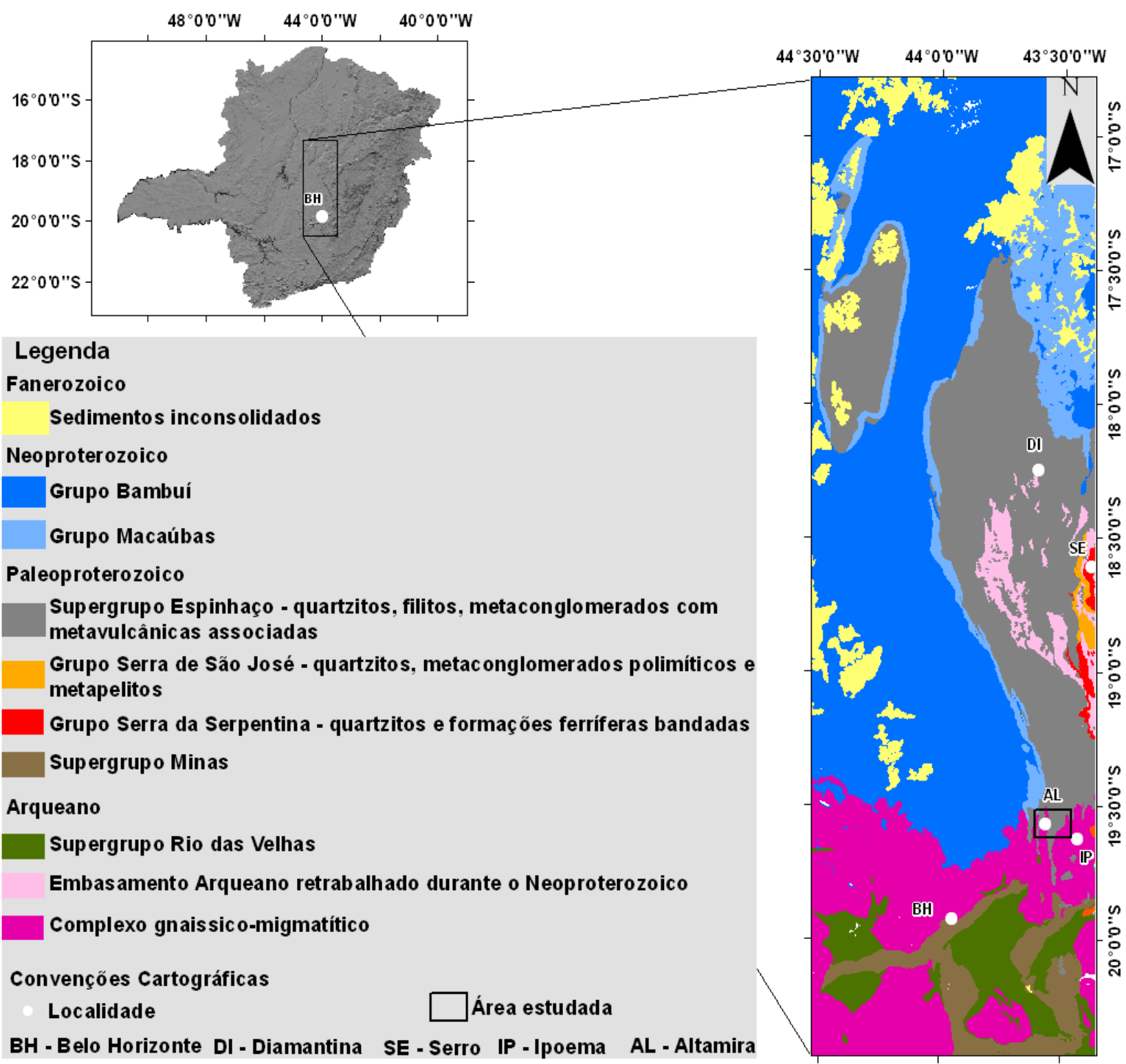

Figura 3 - Serra do Espinhaço Meridional e unidades geológicas regionais adjacentes com a localização da área investigada.

Uhlein (1982) e Knauer \& Grossi-Sad (1995) consideram a Formação São João da Chapada como basal também na borda leste (região de Serro/Conceição do Mato Dentro), diferente de Knauer (1990) que considera a Sequência Itapanhoacanga, definida por Almeida-Abreu et al. (1989), como a base das rochas metassedimentares, e Almeida-Abreu \& Renger (2002) que consideram o Grupo Serro como a unidade basal, sendo este grupo considerado por estes autores como uma variação lateral das unidades descritas na porção central da bacia. Brito Neves et al. (1979) e Machado et al. (1989), utilizando estudos isotópicos em metariolitos da Suíte Metaígnea Conceição do Mato Dentro, consideraram esta suíte como a unidade basal do Supergrupo Espinhaço na borda leste.

Rolim et al. (2016) em uma nova proposta estratigráfica para a borda leste, consideraram a Formação Lapão (Grupo Serra de São José) a unidade basal dos metassedimentos pertencentes ao Supergrupo Espinhaço, sendo uma continuidade 
lateral da Formação São João da Chapada.

Em relação ao arcabouço estrutural, Uhlein et al. (1986) e Rolim (1992) baseados no estilo de deformação e comportamento das rochas aflorantes, caracterizam dois domínios principais de deformação na Serra do Espinhaço Meridional: a leste da Serra do Espinhaço desenvolveu-se uma tectônica de cavalgamentos, na maioria das vezes frontais, de direção N-S e vergentes para oeste, com maior magnitude de deformação, desenvolvendo uma foliação milonítica juntamente com uma conspícua lineação de estiramento que marca a direção de transporte tectônico.

O domínio ocidental se distingue do anterior pela baixa magnitude de deformação, predominando dobras amplas assimétricas com xistosidade plano-axial submeridiana e, eventualmente, estão cortadas por falhas inversas de direção N-S.

Alkmim et al. (2006) definem a Serra do Espinhaço Meridional como um cinturão de dobras e cavalgamentos que limita a borda lestesudeste do Cráton São Francisco em Minas
Gerais. Este cinturão constitui a porção mais ocidental do orógeno Araçuaí (Pedrosa-Soares et al., 2001; Pedrosa-Soares et al., 2008) que foi formado durante a colisão entre os núcleos cratônicos Congo e São Francisco na orogenia Brasiliana/Pan-Africana no Neoproterozoico/ início do Paleozoico. Esta colisão resultou em uma tectônica compressiva que deformou as rochas da região gerando um conjunto de falhas de empurrão com caimento para leste e vergência para oeste.

Silva (2011) caracteriza o arcabouço da Serra do Espinhaço Meridional como um sistema de cavalgamentos do tipo duplex com transporte tectônico para oeste e de abrangência regional.

Em relação ao grau metamórfico, as rochas metassedimentares da Serra do Espinhaço Meridional passaram por um processo de metamorfismo regional de fácies xisto verde média a baixa, registrado pela presença de sericita e clorita na matriz de metaconglomerados e quartzitos, assim como na constituição de filitos e xistos.

\section{REVISÃO DOS ESTUDOS GEOCRONOLÓGICOS NA SERRA DO ESPINHAÇO MERIDIONAL}

Alguns pesquisadores utilizaram estudos geocronológicos para balizar os eventos associados à abertura da bacia Espinhaço. Brito Neves et al. (1979) e Machado et al. (1989) dataram metavulcânicas ácidas intrusivas nas rochas metassedimentares da base da sequência, da região de Conceição do Mato Dentro e Serro, pelo método U-Pb em zircão, encontrando idades de $1.711 \mathrm{Ma}$ e $1.770 \mathrm{Ma}$. Estas idades foram consideradas por estes autores como o início da sedimentação na bacia Espinhaço. Dossin et al. (1993) dataram filitos hematíticos pelo método $\mathrm{Pb}-\mathrm{Pb}$ em zircões, encontrando idade de $1.770 \pm$ $12 \mathrm{Ma}$, assumida como o início da sedimentação da bacia por estes autores. Os filitos hematíticos são rochas de origem ígnea (Knauer \& Schrank, 1994) associadas às rochas metassedimentares da Formação São João da Chapada na região de Diamantina.

Chemale Jr. et al. (2012) e Santos et al. (2013) dataram as unidades basais do Supergrupo Espinhaço (formações Bandeirinha, São João da Chapada e Sopa-Brumadinho) nas regiões dos distritos diamantíferos de Sopa-Guinda e Extração. Foi usado o método U-Pb em zircões detríticos (formações Bandeirinha - quartzito e Sopa-Brumadinho polimítico) e U-Pb em zircão (Formação São João da Chapada - filito hematítico). As idades máximas de deposição encontradas para as formações foram de $1.785 \mathrm{Ma}$ (Formação Bandeirinha), 1.713 Ma (Formação São João da Chapada) e 1.182 Ma (Formação SopaBrumadinho).

A descoberta de um zircão detrítico mais jovem em metaconglomerado polimítico da Formação Sopa-Brumadinho levou estes autores a sugerirem que o preenchimento da bacia Espinhaço em seu setor meridional, ocorreu no mínimo em dois ciclos distintos. Eles dividiram a sequência metassedimentar em duas: Bacia Espinhaço Inferior e Bacia Espinhaço Superior, e sugeriram um gap sedimentar entre elas de aproximadamente 500 Ma. A Bacia Espinhaço Inferior reúne as formações Bandeirinha e São João da Chapada e a Bacia Espinhaço Superior reúne as formações Sopa-Brumadinho, Galho do Miguel e todo o Grupo Conselheiro Mata, este último definido por Dossin et al. (1984).

Rodrigues da Silva (2016) realizou estudos isotópicos em metaconglomerados polimíticos da Formação Sopa-Brumadinho e metavulcânicas associadas a esta formação, nos campos diamantíferos de São João da Chapada, Sopa- 
Guinda e Extração. Foi usado o método U-Pb em zircões detríticos (metaconglomerados polimíticos) e U-Pb em zircão (metavulcânicas) e as idades máximas de deposição encontradas para esta formação foram de $1.706 \pm 2,8 \mathrm{Ma}$ (campos Sopa-Guinda e São João da Chapada) e $1.635 \pm$ $21 \mathrm{Ma}$ (campo de Extração). Estes dados juntamente com dados estratigráficos levaram este autor a sugerir que o preenchimento da bacia Espinhaço em seu setor meridional, ocorreu no mínimo em dois ciclos distintos, porém sem o gap sedimentar sugerido por Chemale Jr. et al. (2012) e Santos et al. (2013). Segundo Rodrigues da Silva (2016) a bacia Espinhaço teria evoluído para leste, sendo o campo de Extração o registro de uma sedimentação não contemporânea da Formação
Sopa-Brumadinho, em relação à sua deposição nos outros campos.

Rolim et al. (2016) e Silveira (2016) dataram quartzitos basais associados às formações ferríferas bandadas nas regiões de Serro, Morro do Pilar e Itapanhoacanga, na borda leste da Serra do Espinhaço Meridional. Foi usado o método U$\mathrm{Pb}$ em zircões detríticos e as idades encontradas foram de $1.719 \pm 24 \mathrm{Ma}$ e $1.683 \mathrm{Ma}$, consideradas por estes autores como as idades máximas de deposição da unidade basal na região, denominada Formação Lapão por Rolim et al. (2016). Eles correlacionaram esta unidade basal com a Formação São João da Chapada, considerando-a como uma continuidade lateral desta formação.

\section{ESTRATIGRAFIA NA REGIÃO DE ALTAMIRA E IPOEMA}

Um novo mapa geológico foi preparado para a área investigada a partir dos dados coletados em campo juntamente com a compilação dos dados geológicos existentes da região, já mencionados anteriormente. As rochas metassedimentares aflorantes e mapeadas nesta região foram divididas em três unidades, denominadas informalmente da base para o topo de: Unidade Basal, Unidade Intermediária e Unidade Superior (Figura 4), sendo a Unidade Basal o alvo dos estudos geocronológicos. Este pacote de rochas metassedimentares tem como embasamento rochas gnáissicas-migmatíticas. Rochas ígneas metabásicas de natureza intrusiva, estão associadas ao conjunto na forma de diques e sills (Figura 4).

\section{Embasamento Gnáissico-Migmatítico}

É constituído por rochas de composição granítica a granodiorítica com bandas máficas e félsicas de espessura que varia de 1 a $2 \mathrm{~cm}$, dobradas (Figura 5). As bandas máficas são constituídas por biotita (maioria), anfibólio e plagioclásio enquanto as bandas félsicas são constituídas por quartzo e feldspato potássico. Afloram nas regiões de cotas mais baixas, sendo os melhores afloramentos nos vales do rio Preto e dos córregos Fundo e da Prata.

\section{Unidade Basal}

Esta unidade é formada por metaconglomerados/metabrechas e quartzitos (Figura 6). Ela está sobreposta diretamente ao embasamento gnáissico. Os metaconglomerados/ metabrechas marcam a base da unidade e possuem de $1 \mathrm{~m}$ a $5 \mathrm{~m}$ de espessura. Os contatos de base e topo são bruscos, sendo o contato basal tectônico e o contato de topo possui superfície irregular (Figura 6A). Os metaconglomerados são suportados pela matriz, formada por mica branca e quartzo com granulação fina a média, foliada.

O arcabouço é formado por clastos bem selecionados tamanho seixo com predomínio de quartzo de veio e quartzito micáceo orientados paralelos à foliação da matriz (Figura 6B). Subordinadamente ocorrem clastos de quartzito ferruginoso, filito negro e formação ferrífera. A metabrecha ocorre predominantemente na porção leste da área.

É suportada pela matriz formada predominantemente por quartzo e pouca mica, granulação fina a média, foliada. $\mathrm{O}$ arcabouço é formado por clastos mal selecionados de tamanho grânulo a bloco com predomínio de clastos de formação ferrífera e subordinadamente de quartzitos e quartzo de veio, são angulosos e de baixa esfericidade e estão orientados paralelamente à foliação da matriz (Figuras 6C e 6D).

Assim como os metaconglomerados, as metabrechas possuem contatos de base e topo bruscos, sendo o contato basal tectônico e o contato de topo irregular. Tanto o metaconglomerado como a metabrecha não possuem uma continuidade lateral ao longo de sua direção ou no sentido do seu mergulho, sendo totalmente recobertos pelo quartzito da mesma unidade.

Os quartzitos dessa unidade são brancos, de granulação fina a média e com mica branca associada, algumas vezes formando planos 
submilimétricos entre os estratos planoparalelos, predominantemente constituídos por quartzo (Figuras 7A e 7B). Em alguns locais os quartzitos estão bem recristalizados e com uma coloração acinzentada. Estruturas primárias preservadas como estratificação plano-paralela e marcas onduladas assimétricas podem ser identificadas (Figuras 7C e 7D).

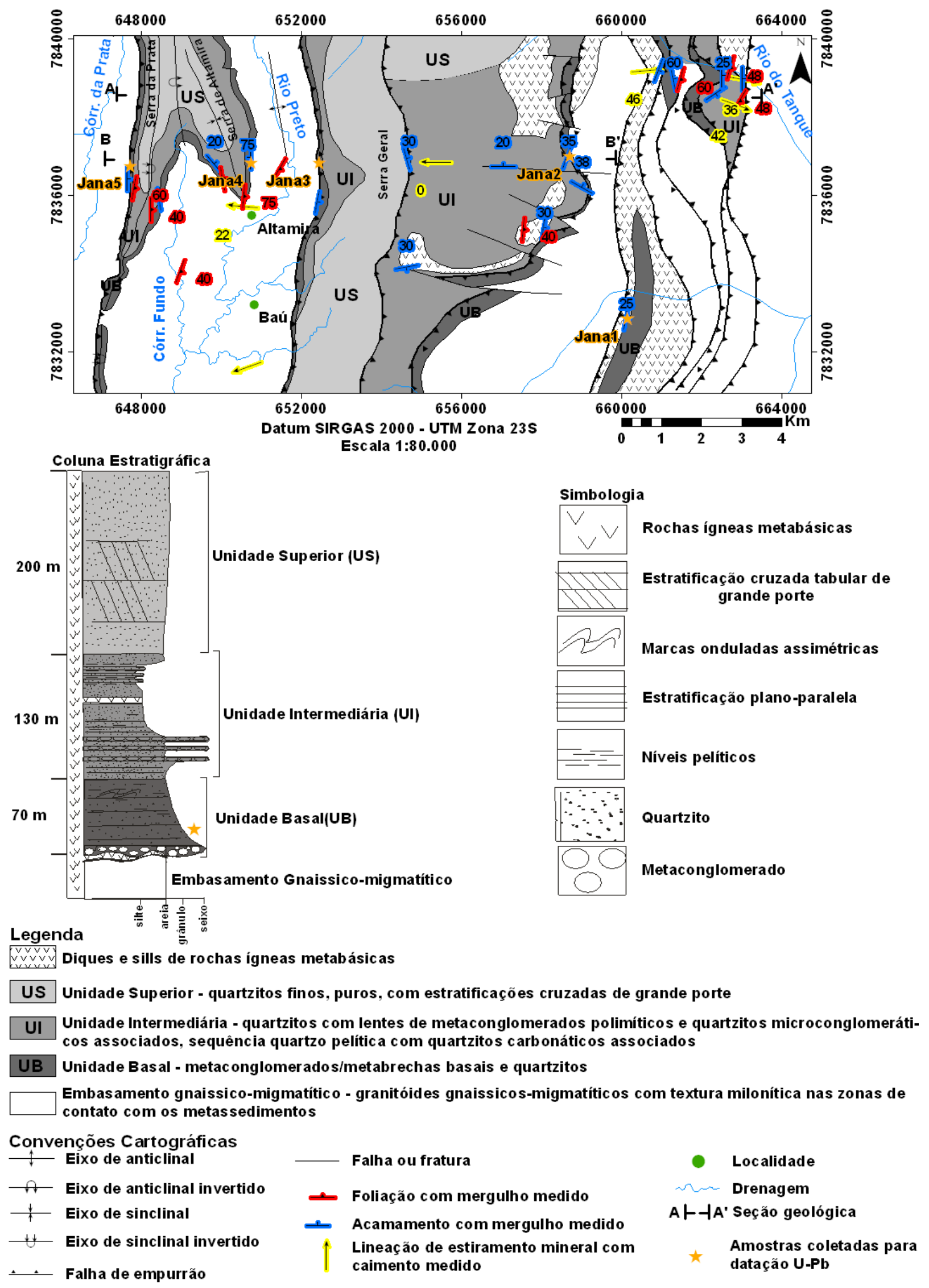

Figura 4 - Mapa geológico e coluna estratigráfica das regiões de Altamira e Ipoema com a localização das amostras coletadas para estudos geocronológicos. 


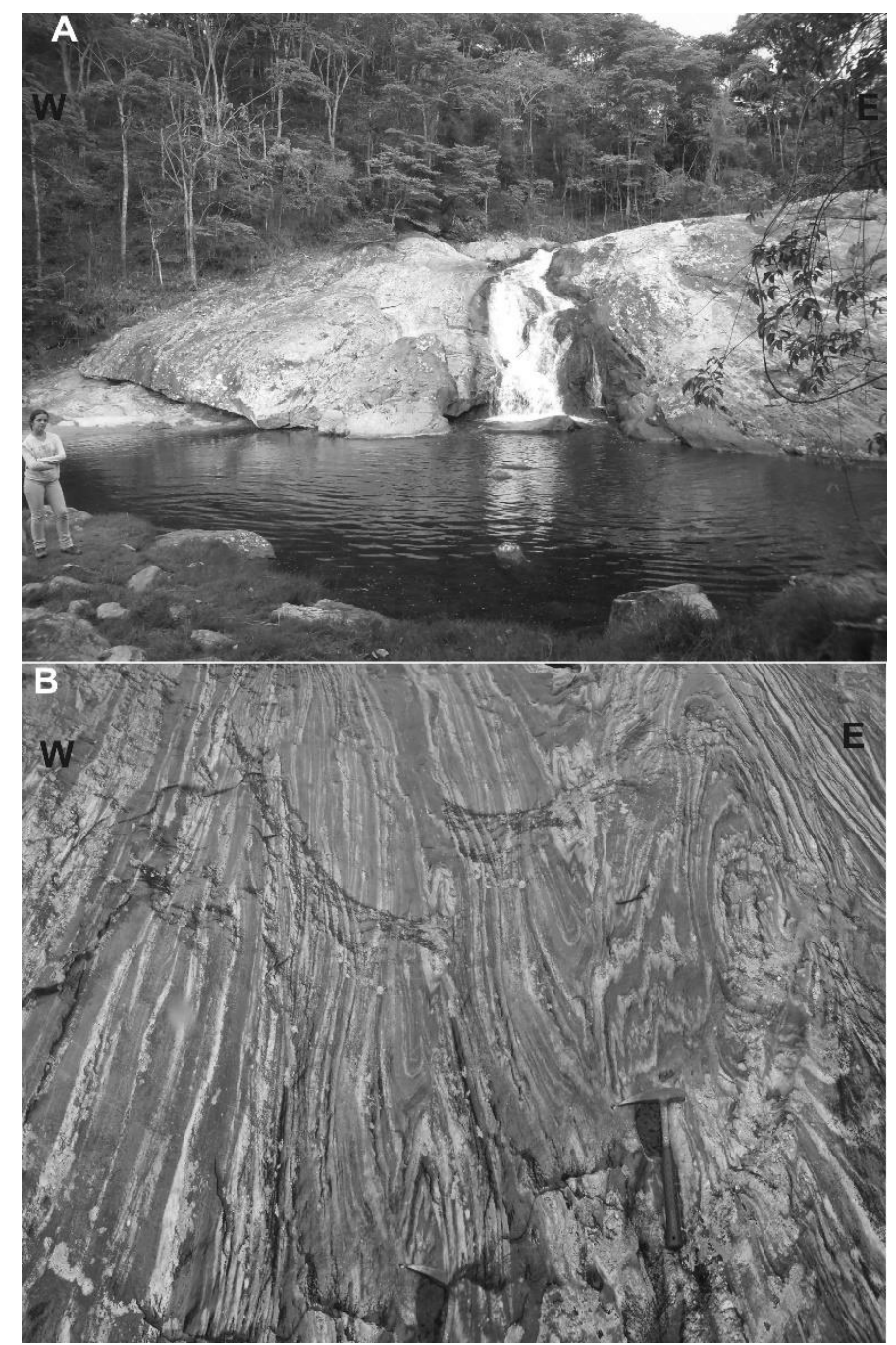

Figura 5 - Embasamento gnáissico-migmatítico. A) Afloramento no Rio Preto. B) Detalhe do afloramento mostrando o bandamento dobrado.
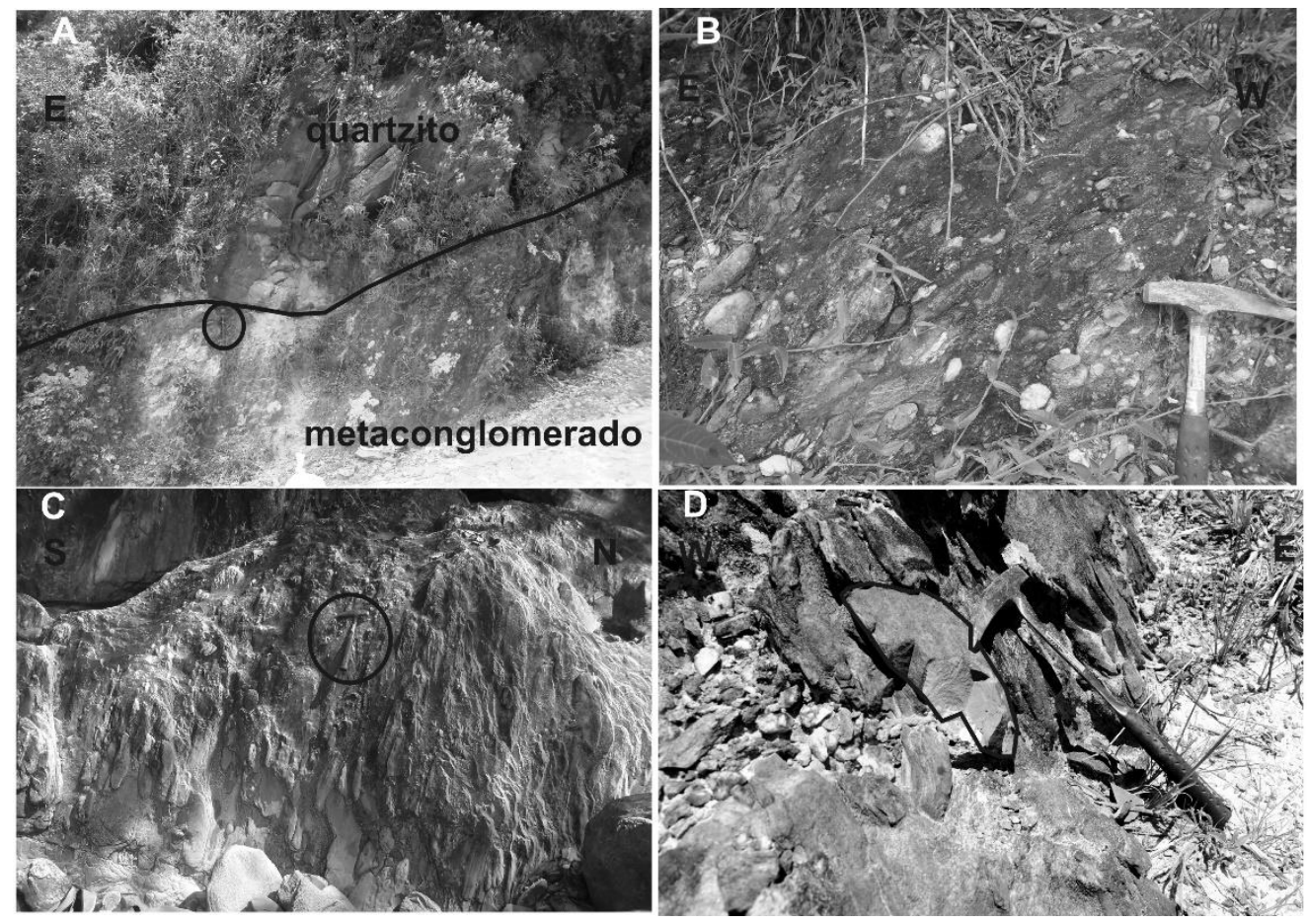

Figura 6 - Metaconglomerado da Unidade Basal. A) Contato irregular de topo do metaconglomerado com o quartzito. B) Detalhe do conglomerado com clastos orientados paralelamente à foliação da matriz. C) Afloramento de metabrecha com clastos de formação ferrífera orientados paralelos à foliação da matriz. D) Detalhe de um dos clastos de formação ferrífera. 


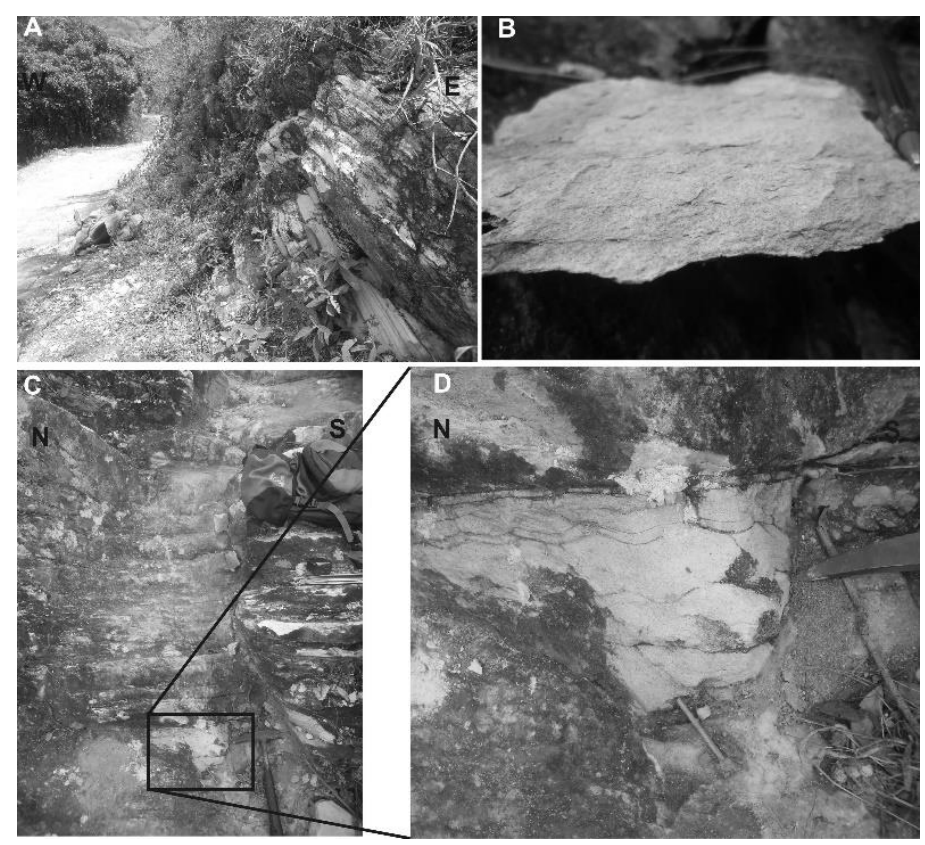

Figura 7 - Quartzito da Unidade Basal. A) Afloramento com estratos paralelos. B) Detalhe de amostra de mão mostrando os planos submilimétricos formados por mica branca. C) estruturas primárias preservadas (estratos plano-paralelos e marcas de ondas assimétricas). D) Detalhe do afloramento mostrando as marcas de onda assimétricas.

\section{Unidade Intermediária}

Esta unidade é formada na porção basal por quartzitos finos a médios intercalados com metaconglomerados polimíticos (Figuras 8A e 8B), gradando em direção ao topo para uma sequência de quartzo filitos, filitos e quartzitos finos.

Os quartzitos são de granulação média a grossa, esbranquiçados e possuem estruturas sedimentares preservadas como estratos plano- paralelos.

Os metaconglomerados são suportados pelos clastos, a matriz é formada por quartzo e mica branca com granulação fina a média, foliada. $\mathrm{O}$ arcabouço é formado por clastos mal selecionados de tamanho grânulo a bloco de quartzo de veio, quartzito micáceo, quartzito ferruginoso, filito negro e formação ferrífera e estão orientados paralelamente à foliação da matriz.

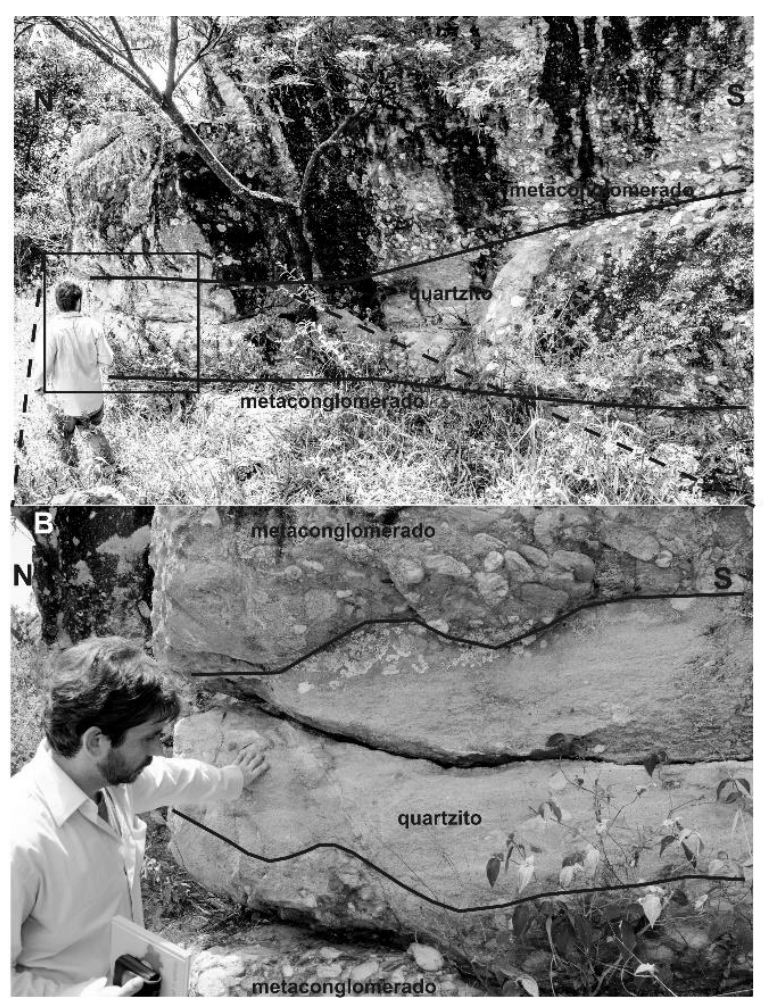

Figura 8 - Unidade Intermediária. A) Afloramento de metaconglomerado intercalado com quartzito. B) Detalhe do afloramento. 


\section{Unidade Superior}

Esta unidade é caracterizada por um espesso pacote de quartzitos esbranquiçados, com granulação fina a média e grãos subarredondados a arredondados.

É uma unidade monótona, sem muita variação faciológica. Aflora nas porções mais altas da área (topo das serras), sendo facilmente diferenciada por imagens de satélite. Estruturas sedimentares presentes e características desta unidade são estratificações cruzadas tabulares de grande porte (Figura 9).

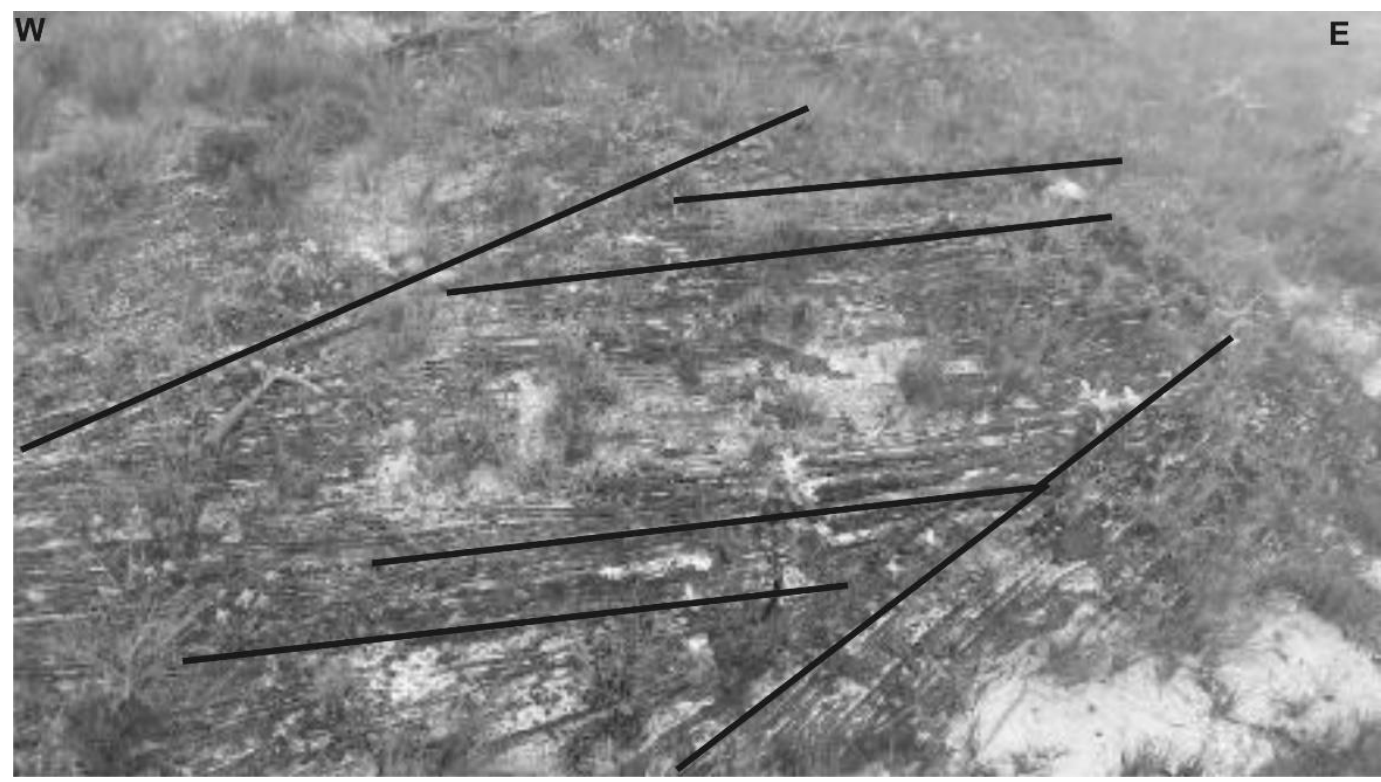

Figura 9 - Estratificações cruzadas tabulares em quartzitos da Unidade Superior.

\section{GEOLOGIA ESTRUTURAL NA REGIÃO DE ALTAMIRA E IPOEMA}

Devido ao arcabouço tectônico identificado, a área investigada foi dividida em dois domínios estruturais: Domínio Oeste e Domínio Leste (Figura 10).

No Domínio Oeste as rochas metassedimentares, assim como o embasamento, estão dobradas formando sinclinais e anticlinais em escala macroscópica (Figura 10). As dobras são abertas, inclinadas, com caimento dos eixos para NNW.

São levemente assimétricas e com vergência para oeste. A foliação associada a estes dobramentos é plano-axial, com trend direcional aproximadamente N-S com mergulhos médios a altos para o quadrante leste. Esta foliação pode ser identificada em todas as unidades metassedimentares e é formada pela orientação dos minerais micáceos presentes nas rochas. Em um destes dobramentos há inversão da estratigrafia, identificada em campo (flanco leste da Serra da Prata) pela relação espacial entre o acamamento sedimentar e a foliação, com o acamamento tendo ângulo de mergulho maior que o ângulo de mergulho da foliação.

No Domínio Leste prevalece uma tectônica de cavalgamentos frontais formando cavalos tectônicos de direção aproximada N-S vergentes para oeste (Figura 10). Estes cavalgamentos são responsáveis por uma geometria sigmoidal, penetrativa em todas as escalas. Estas falhas de empurrão também atingiram o embasamento que foi sobreposto ao conjunto de rochas metassedimentares.

Nos dois domínios ocorre uma zona de cisalhamento definida por uma superfície de descolamento basal que corresponde a uma descontinuidade estrutural de escala regional. No Domínio Oeste esta superfície coincide com as falhas de empurrão (Figura 10).

Estas diferenças no arcabouço estrutural dos domínios refletem no posicionamento espacial das litologias em forma de repetição das unidades. A repetição das unidades no Domínio Oeste é devido aos dobramentos, enquanto no Domínio Leste elas se repetem devido ao empilhamento causado pelos cavalgamentos.

\section{ESTUDOS GEOCRONOLÓGICOS}

Foram coletadas 05 amostras de quartzitos pertencentes à Unidade Basal onde quatro delas estão localizadas ao longo de um mesmo perfil geoló- gico regional (Figura 4), mas somente 04 foram analisadas (Figura 11), onde 03 estão localizadas ao longo do mesmo perfil (Jana 2, Jana 3 e Jana 5). 

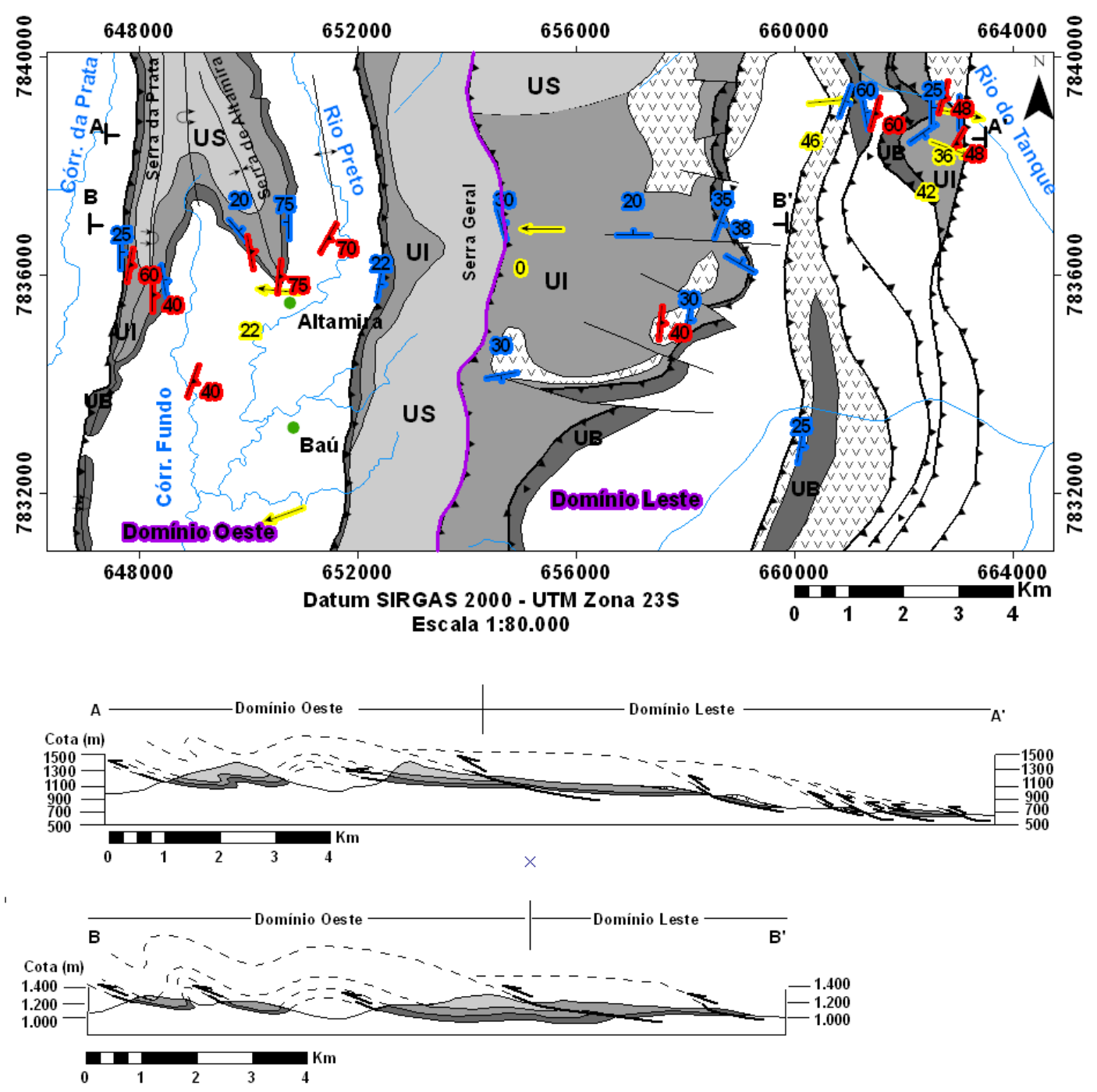

Legenda

vrvv Diques e sills de rochas ígneas metabásicas

US Unidade Superior - quartzitos finos, puros, com estratificações cruzadas de grande porte

UI Unidade Intermediária - quartzitos com lentes de metaconglomerados polimíticos e quartzitos microconglomeráticos associados, sequência quartzo pelític a com quartzitos $c$ arbonáticos associados

UB Unidade Basal - metaconglomerados/metabrechas basais e quartzitos

Embasamento gnaissico-migmatítico - granitóides gnaissicos-migmatíticos com textura milonítica nas zonas de contato com os metassedimentos
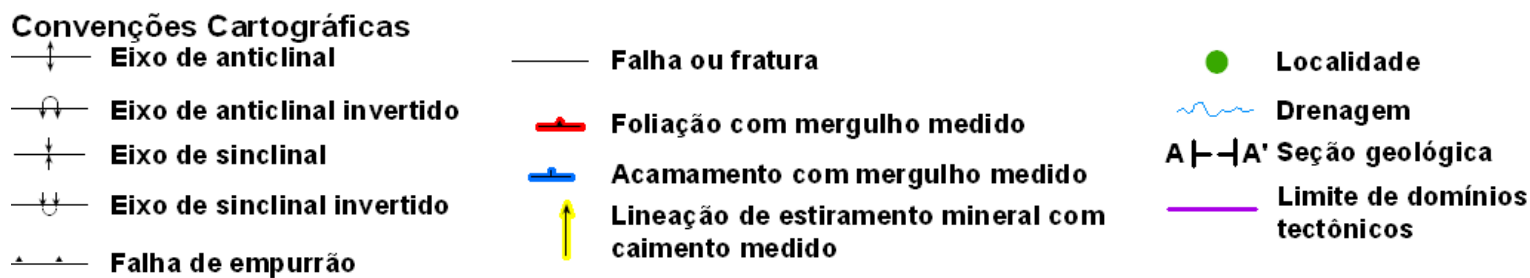

Figura 10 - Mapa geológico e seções geológicas mostrando as diferenças estruturais entre os dois domínios tectônicos.

\section{Amostra Jana 1}

Os estudos geocronológicos desta amostra foram feitos em 21 zircões representados em um diagrama concórdia (Figura 12), dos quais 17 resultaram em concordância superior a $95 \%$.As idades obtidas mostram que a proveniência destes zircões pode ser reunida em três grupos: Arqueano
(28\%), Riaciano (67\%) e Orosiriano (5\%). As idades ${ }^{207} \mathrm{~Pb} /{ }^{206} \mathrm{~Pb}$ arqueanas estão entre $2.671 \pm 24$ Ma e $3.357 \pm 13 \mathrm{Ma}$, as idades riacianas estão entre $2.072 \pm 9 \mathrm{Ma}$ e $2.176 \pm 10 \mathrm{Ma}$ e a idade orosiriana é de $2.033 \pm 9 \mathrm{Ma}$, sendo esta última, a idade mais nova encontrada nesta amostra e representada por um único zircão no spot C.4-3 (Figura 13). 


\begin{tabular}{|c|c|c|c|c|c|}
\hline REGIÃO & AMOSTRA & $\begin{array}{c}\text { COORDENADAS } \\
\text { E (UTM) }\end{array}$ & $\begin{array}{c}\text { COORDENADAS } \\
\text { N(UTM) }\end{array}$ & LITOLOGIA & $\begin{array}{c}\text { DESCRIÇÃOE } \\
\text { LOCALIZAÇÃO } \\
\end{array}$ \\
\hline Ipoema & Jana1 & 660157 & 7832823 & Quartzito & $\begin{array}{l}\text { Rocha } \\
\text { esbranquiçada/amarelada com } \\
\text { estratos plano-paralelos e } \\
\text { marcas onduladas assimétricas, } \\
\text { granulação fina a média. } \\
\text { Estrada Ipoema-Morro } \\
\text { Redondo } \\
\end{array}$ \\
\hline $\begin{array}{l}\text { Morro } \\
\text { Redondo }\end{array}$ & Jana2 & 658704 & 7836984 & Quartzito & $\begin{array}{l}\text { Rocha } \\
\text { esbranquiçada/amarelada com } \\
\text { estratos plano-paralelos e } \\
\text { granulação fina a média. Morro } \\
\text { Redondo }\end{array}$ \\
\hline \multirow{3}{*}{ Altamira } & Jana3 & 652435 & 7836814 & Quartzito & $\begin{array}{l}\text { Rocha } \\
\text { esbranquiçada/acinzentada } \\
\text { com estratos plano-paralelos e } \\
\text { granulação fina a média. Base } \\
\text { da Serra Geral, leste de } \\
\text { Altamira. }\end{array}$ \\
\hline & Jana4 & 650738 & 7836811 & Quartzito & $\begin{array}{l}\text { Rocha } \\
\text { esbranquiçada/amarelada com } \\
\text { estratos plano-paralelos e } \\
\text { granulação fina a média. Base } \\
\text { da Serra do Morro do } \\
\text { Cruzeiro, lado leste. }\end{array}$ \\
\hline & Jana5 & 647717 & 7836739 & Quartzito & $\begin{array}{l}\text { Rocha branca com estratos } \\
\text { plano-paralelos com planos } \\
\text { submilimétricos formados por } \\
\text { mica branca. Base da Serra da } \\
\text { Prata, lado oeste, oeste de } \\
\text { Altamira. }\end{array}$ \\
\hline
\end{tabular}

Figura 11 -Amostras coletadas para análises isotópicas. Amostra Altamira Jana4 foi excluída da análise.

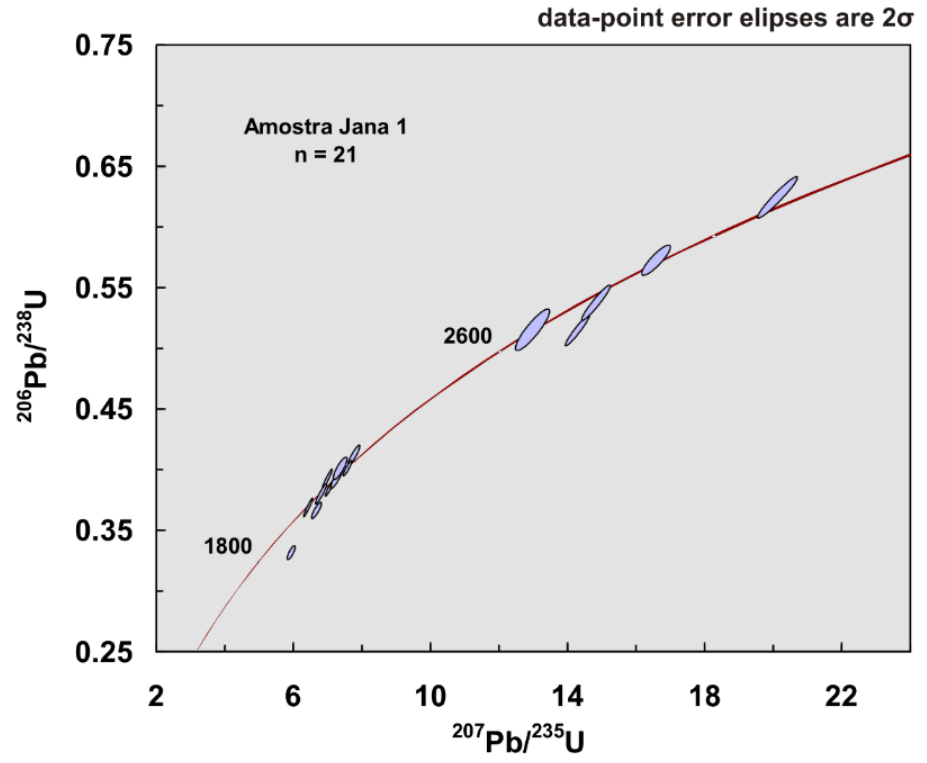

Figura 12 - Diagrama concórdia das idades U-Pb da amostra Jana 1.

A maioria dos grãos são arredondados a bem arredondados, com baixa esfericidade e de dimensões que variam de $100 \mu \mathrm{m}$ a $275 \mu \mathrm{m}$. A estrutura interna predominante dos grãos é o não zoneamento, com coloração cinza claro a escuro, alguns esbranquiçados. Existem alguns grãos com zoneamento oscilatório e um zircão metamítico. Em geral, as bordas dos grãos estão corroídas e alguns deles possuem inclusões.

\section{Amostra Jana 2}

Nesta amostra os estudos geocronológicos foram feitos em 20 zircões representados em um diagrama concórdia (Figura 14) e todos eles apresentaram concordância acima de $95 \%$. 


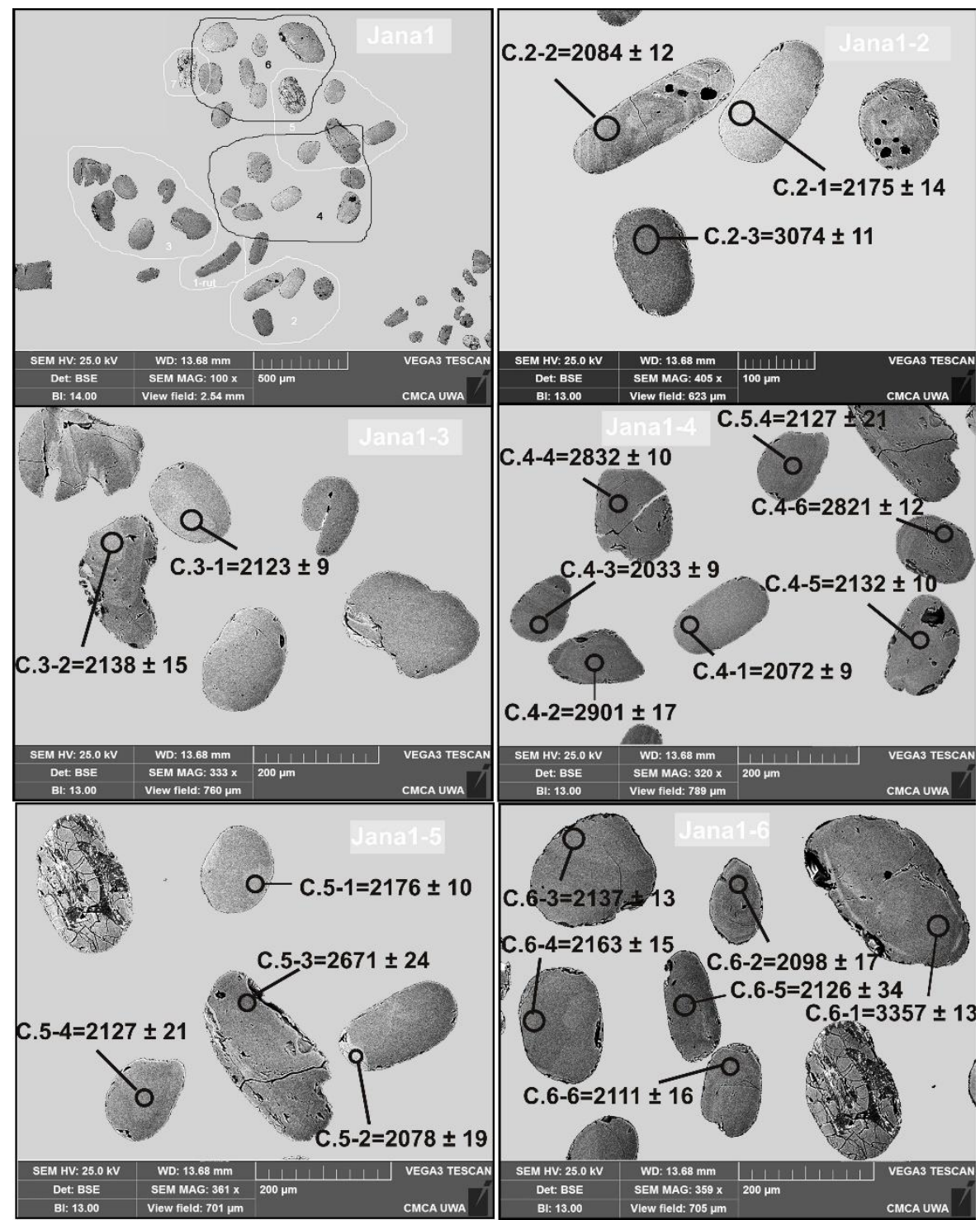

Figura 13 - Imagem BSE dos grãos de zircões datados na amostra Jana 1. Círculos representam os locais analisados.

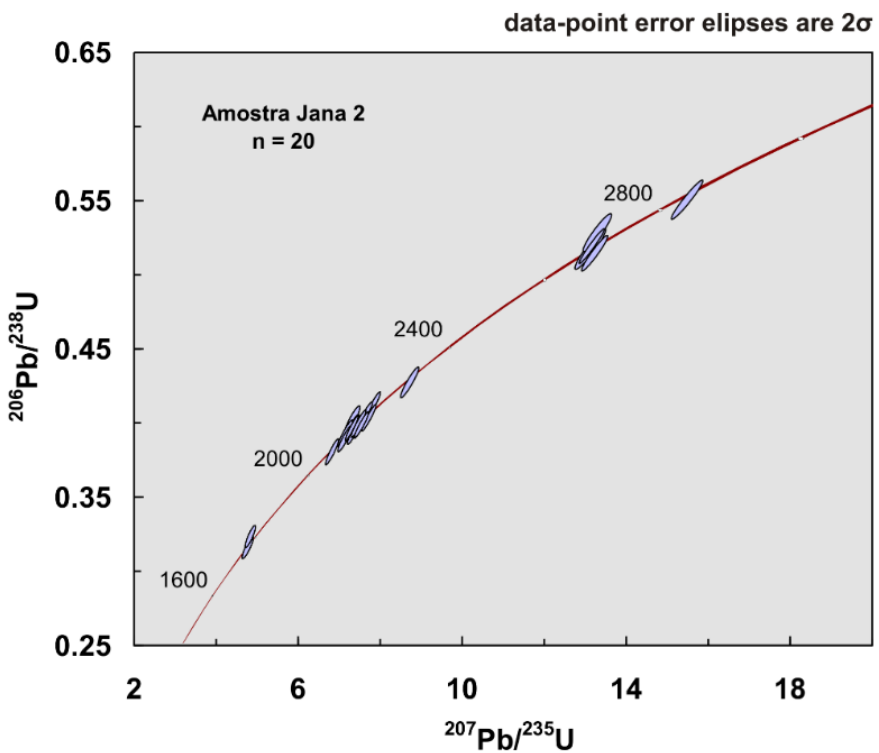

Figura 14 - Diagrama concórdia das idades U-Pb da amostra Jana 2.

As idades obtidas mostram que a proveniência dos zircões detríticos pode ser reunida em quatro grupos: Arqueano (25\%), Sideriano (5\%),
Riaciano (60\%) e Estateriano (10\%). As idades ${ }^{207} \mathrm{~Pb} /{ }^{206} \mathrm{~Pb}$ arqueanas estão entre $2.670 \pm 13 \mathrm{Ma}$ e $2.853 \pm 9 \mathrm{Ma}$, a idade sideriana está 
representada por um único zircão de idade 2.311 $\pm 13 \mathrm{Ma}$, as idades riacianas estão entre $2.086 \pm$ $13 \mathrm{Ma}$ e $2.202 \pm 10 \mathrm{Ma}$ e as idades estaterianas estão representadas por dois zircões de idades
$1.773 \pm 19$ Ma e $1.751 \pm 19$ Ma, encontradas nos spots E.5-1 e E.5-5 respectivamente (Figura 15). Estas foram as idades mais jovens encontradas nesta amostra.

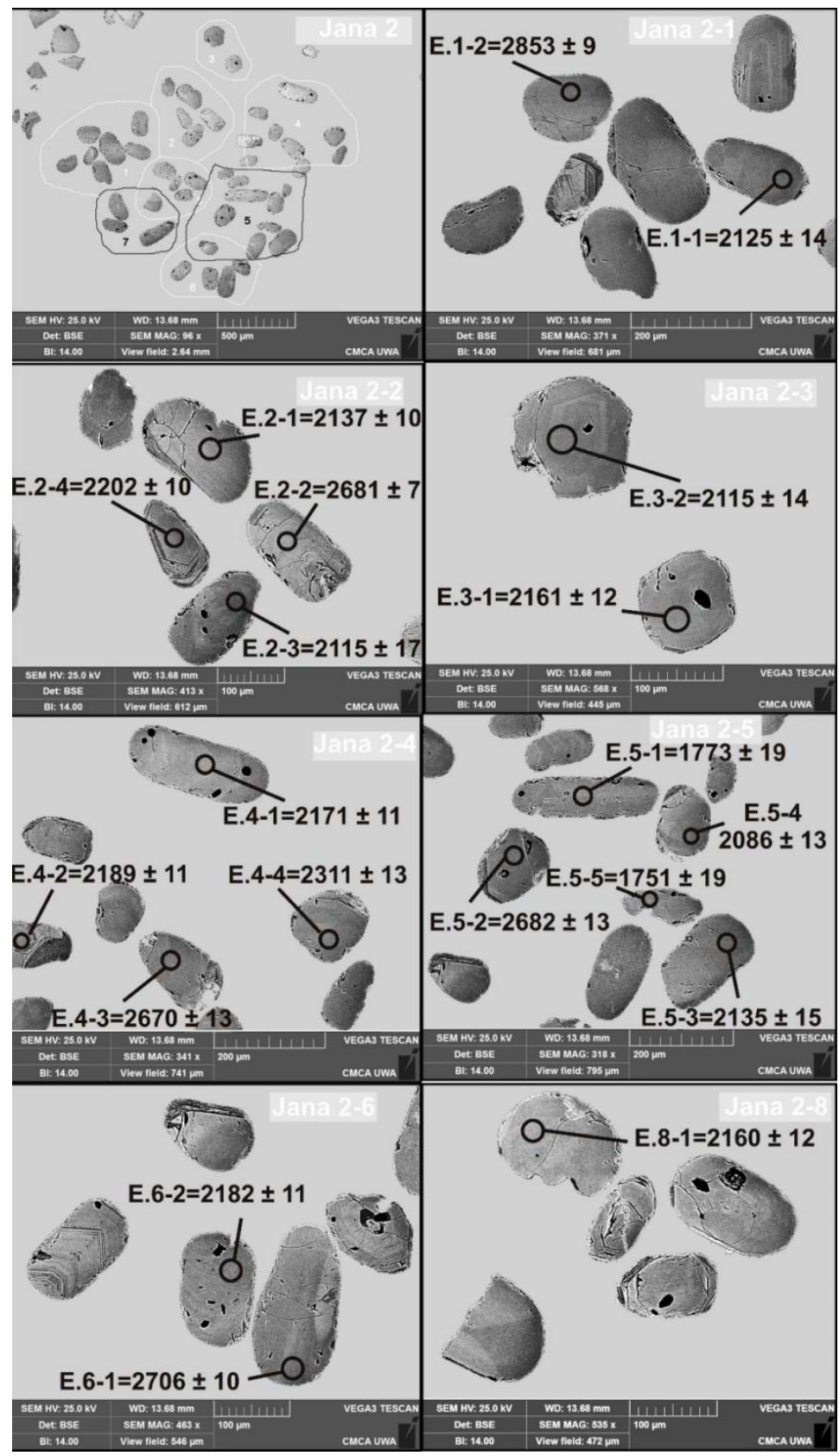

Figura 15 - Imagem BSE dos grãos de zircões datados na amostra Jana 2. Círculos representam os locais analisados.

A maioria dos grãos são arredondados a bem arredondados, com baixa esfericidade e de dimensões que variam de $75 \mu \mathrm{m}$ a $275 \mu \mathrm{m}$.

Os grãos podem apresentar uma estrutura interna não zoneada e/ou com zoneamento oscilatório. A coloração varia de cinza claro a cinza escuro, sendo que alguns grãos possuem porções esbranquiçadas. As bordas dos grãos possuem feições de corrosão e alguns deles possuem inclusões.

\section{Amostra Jana 3}

Nesta amostra os estudos isotópicos foram feitos em 19 zircões e 01 rutilo que apresentou idade de $2.073 \pm 20 \mathrm{Ma}$. O diagrama concórdia foi feito apenas com os dados referentes aos zircões (Figura 16) onde todos apresentaram concordância acima de $95 \%$.

As idades obtidas mostram que a proveniência dos zircões detríticos pode ser reunida em três grupos: Arqueano (26\%), Riaciano (69\%) e Orosiriano (5\%). As idades ${ }^{207} \mathrm{~Pb} /{ }^{206} \mathrm{~Pb}$ arqueanas estão entre $2.681 \pm 12$ Ma e $2.929 \pm 14 \mathrm{Ma}$, as idades riacianas estão entre $2.058 \pm 11 \mathrm{Ma}$ e $2.195 \pm 12 \mathrm{Ma}$, e a idade 
orosiriana está representada por um único zircão de idade $2.019 \pm 27 \mathrm{Ma}$, sendo esta a idade mais nova encontrada nesta amostra no spot A.4-1 (Figura 17).

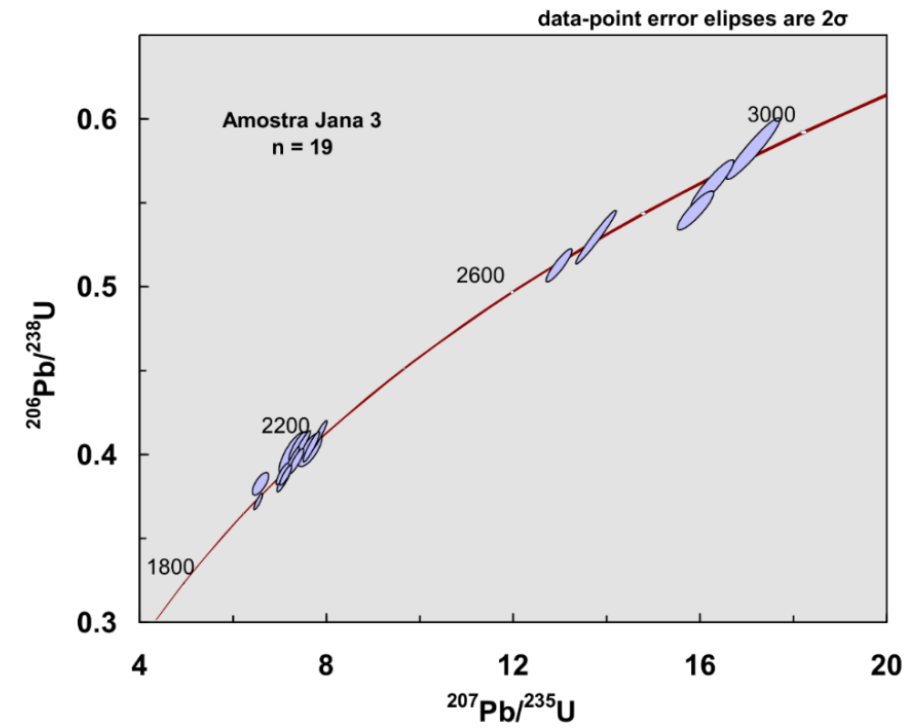

Figura 16 - Diagrama concórdia das idades U-Pb da amostra Jana 3.

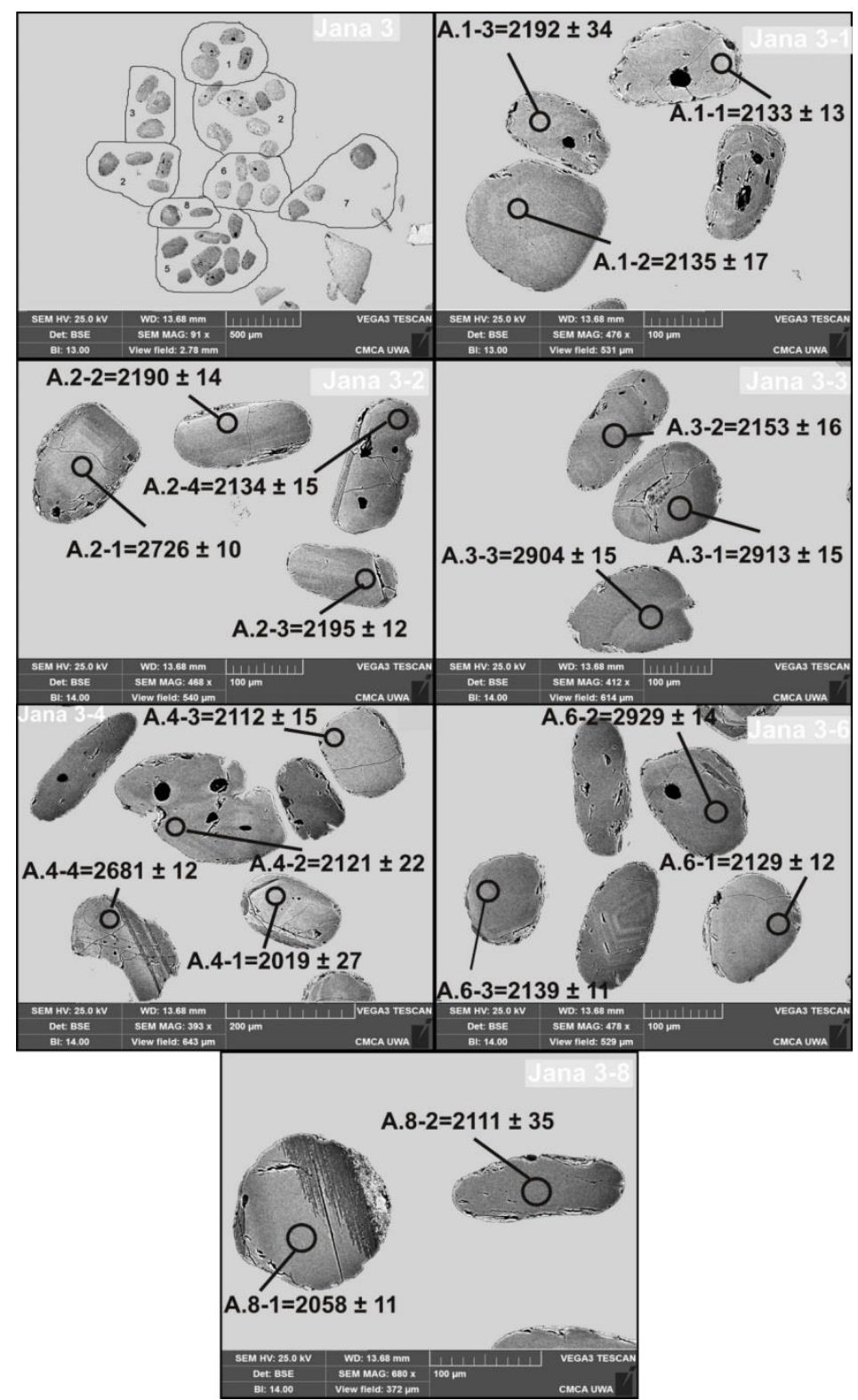

Figura 17 - Imagem BSE dos grãos de zircões datados na amostra Jana 3. Os círculos representam os locais analisados. São Paulo, UNESP, Geociências, v. 38, n. 3, p. 611 - 637, 2019 
A maioria dos grãos são arredondados a bem arredondados, com baixa esfericidade, com exceção de quatro zircões que possuem esfericidade média a alta (A.3-1, A.6-1, A.6-3 e A.8-1). As dimensões variam de $125 \mu \mathrm{m}$ a $265 \mu \mathrm{m}$.

Os grãos possuem uma estrutura interna predominante de não zoneamento, com alguns grãos possuindo zoneamento oscilatório. A coloração varia de cinza claro a cinza escuro. As bordas dos grãos possuem feições de corrosão e alguns deles possuem inclusões.

\section{Amostra Jana 5}

Nesta amostra foram utilizados 17 zircões nos estudos geocronológicos que foram representados em um diagrama concórdia (Figura 18) e 15 deles apresentaram concordância acima de $95 \%$.

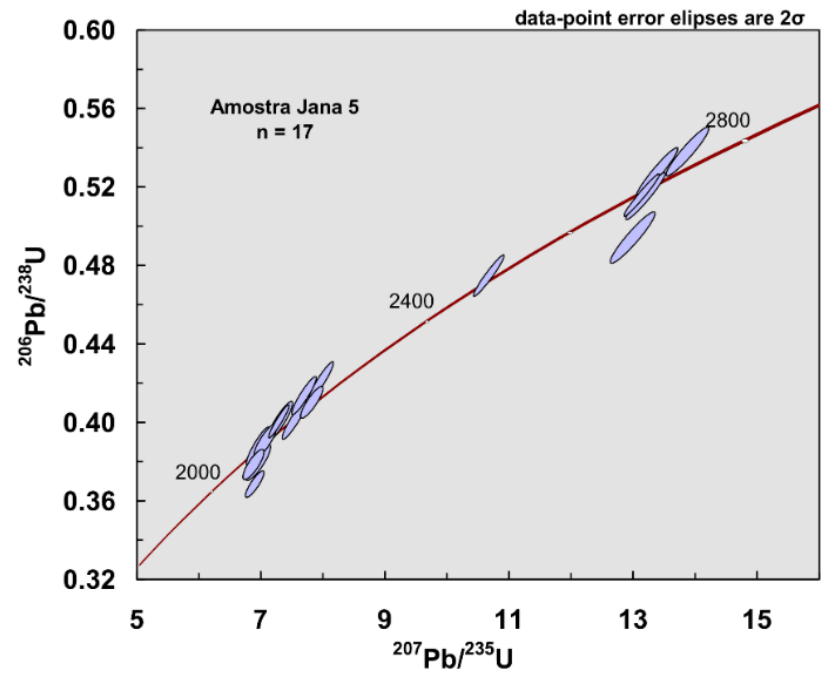

Figura 18 - Diagrama concórdia das idades U-Pb da amostra Jana 5.

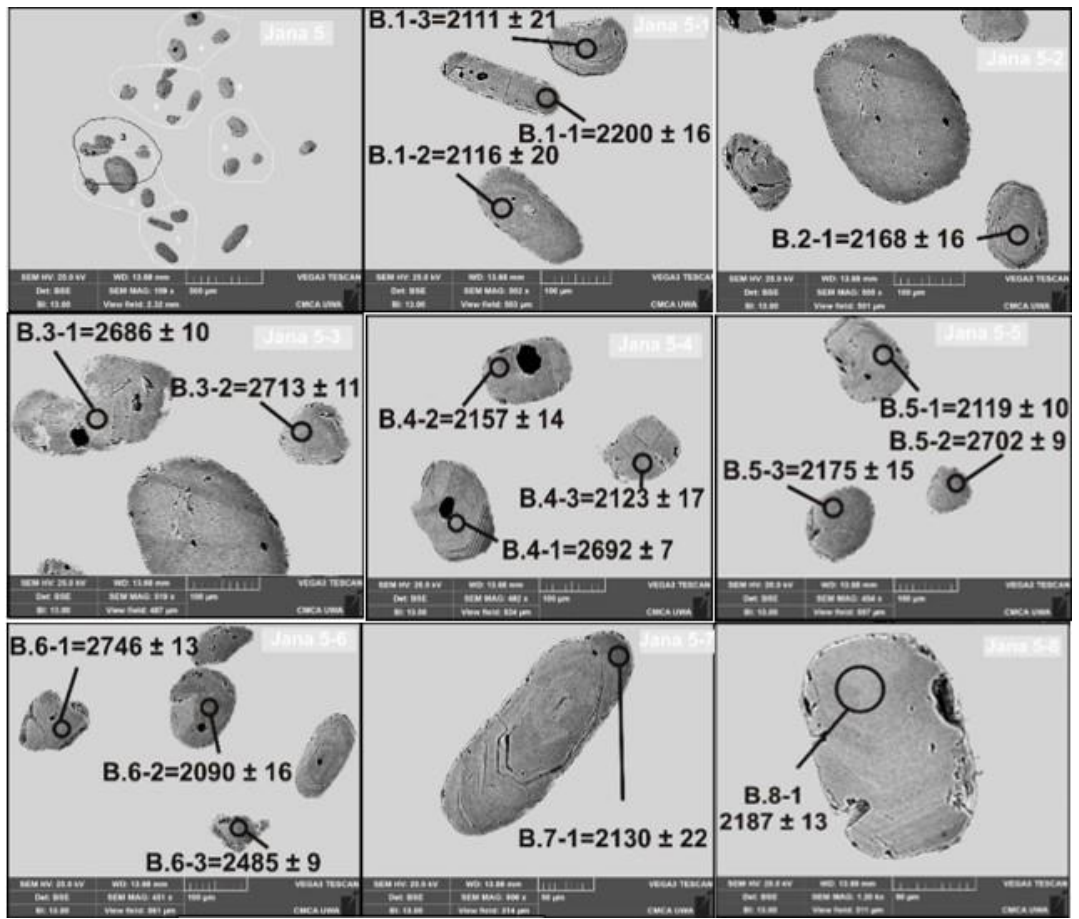

Figura 19 - Imagem BSE dos grãos de zircões datados na amostra Jana 5. Os círculos representam os locais analisados.

As idades obtidas mostram que a proveniência dos zircões detríticos pode ser reunida em três grupos: Arqueano (29\%), Sideriano (6\%) e Riaciano $(65 \%)$. As idades ${ }^{207} \mathrm{~Pb} /{ }^{206} \mathrm{~Pb}$ arqueanas estão entre $2.686 \pm 10 \mathrm{Ma}$ e $2.746 \pm 13 \mathrm{Ma}$, a idade sideriana está representada por um único zircão de idade $2.485 \pm 9 \mathrm{Ma}$, as idades riacianas estão entre $2.090 \pm 16 \mathrm{Ma}$ e $2.200 \pm 16 \mathrm{Ma}$, sendo a idade mais nova encontrada nesta amostra, de $2.090 \pm 16 \mathrm{Ma}$ no spot B.6-2 (Figura 19).

A maioria dos grãos são arredondados a bem arredondados com baixa esfericidade, à exceção de três zircões que possuem esfericidade média a alta (B.5-2, B.5-3 e B.6-2).

As dimensões dos zircões desta amostra variam de $65 \mu \mathrm{m}$ a $250 \mu \mathrm{m}$. A coloração varia de 
cinza claro a cinza escuro e as bordas dos grãos possuem feições de corrosão e alguns deles possuem inclusões.

O histograma de probabilidade relativa foi feito a partir da análise das idades de todas as amostras em conjunto, considerando que todas elas pertencem à mesma unidade estratigráfica. Sendo assim, as idades de 77 zircões e 1 rutilo foram utilizadas, totalizando 78 amostras (Figura 20, Tabela 1, 2, 3 e 4).

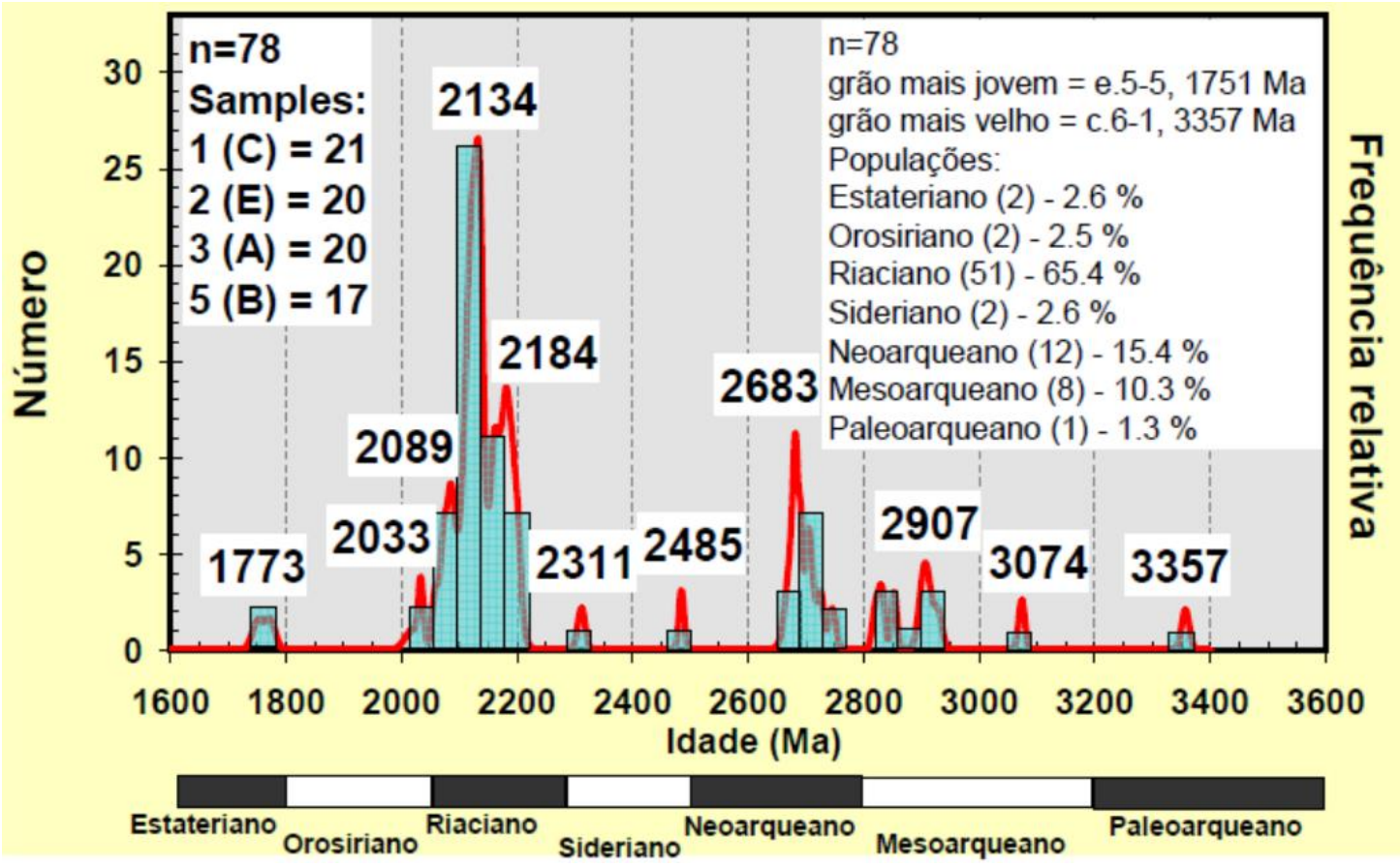

Figura 20 - Histograma de idades ${ }^{207} \mathrm{~Pb} /{ }^{206} \mathrm{~Pb}$ de 77 zircões e 1 rutilo da Unidade Basal.

\section{CONCLUSÕES}

As idades encontradas em todas as amostras e representadas no histograma, mostram que os zircões detríticos do quartzito basal na sucessão de rochas metassedimentares da região de Altamira e Ipoema, denominada neste trabalho de Unidade Basal, podem ser reunidas em 5 grupos: Arqueano (27\%), Sideriano (2,6\%), Riaciano $(65,4 \%)$, Orosiriano $(2,5 \%)$ e Estateriano $(2,6 \%)$. Estes dados mostram que as áreas fontes dos sedimentos são predominantemente de terrenos riacianos $(2,3-2,05 \mathrm{Ga})$ seguidos de terrenos arqueanos $(2,5-4,0 \mathrm{Ga})$, sideriano $(2,3-2,5 \mathrm{Ga})$, orosiriano $(1,8-2,05 \mathrm{Ga})$ e estateriano $(1,6-1,8$ $\mathrm{Ga})$. Em relação aos zircões de idades arqueanas predominam os neoarqueanos $(2,5-2,8 \mathrm{Ga})$ seguidos pelos mesoarqueanos $(2,8-3,2 \mathrm{Ga})$ e um único zircão de idade paleoarqueana $(3,2-3,6$ $\mathrm{Ga})$.

Dados de paleocorrentes na Serra do Espinhaço Meridional (Almeida-Abreu, 1993; Martins-Neto, 1998; Silva, 1998) e modelos paleogeográficos (Almeida-Abreu, 1993; Almeida-Abreu \& Pflug, 1994; Silva, 1998; Martins-Neto, 1998, 2000; Rodrigues da Silva, 2016) mostram que o preenchimento da bacia Espinhaço no setor meridional, representado pelas rochas metassedimentares das três formações basais (Bandeirinha, São João da Chapada e SopaBrumadinho) ocorreu de oeste para leste com o preenchimento de hemigrabens de direção N-S que funcionavam como calhas que tinham seu transporte interno de sedimento de norte para sul. Lançando mão destas informações, algumas correlações em relação às rochas que serviram de fonte dos sedimentos na região de Altamira e Ipoema, podem ser feitas.

Nos domínios da Serra do Espinhaço Meridional não existem registros de rochas paleoarqueanas, mas levando em consideração as paleocorrentes e a idade encontrada $(3.357 \pm 13$ Ma, amostra Jana 1 spot C.6-1), pode ser atribuído às rochas gnáissicas de terrenos TTG (tonalíticotrondhjemítico-granodioríticos) do Bloco Gavião (Cráton São Francisco) uma possível fonte para este zircão. Estas rochas possuem idades que variam de 3,4 Ga a 3,2 Ga (Barbosa \& Sabaté, 2004) e a idade paleoarqueana encontrada se encaixa neste intervalo do tempo geológico. Outro fator é a posição geográfica deste bloco que está localizado a norte da bacia o que lhe permitiria, de acordo com as paleocorrentes, contribuir com o aporte sedimentar dos hemigrabens. 
Tabela 1 - Dados analíticos referentes aos estudos isotópicos U-PB em zircões detríticos da amostra Jana 1.

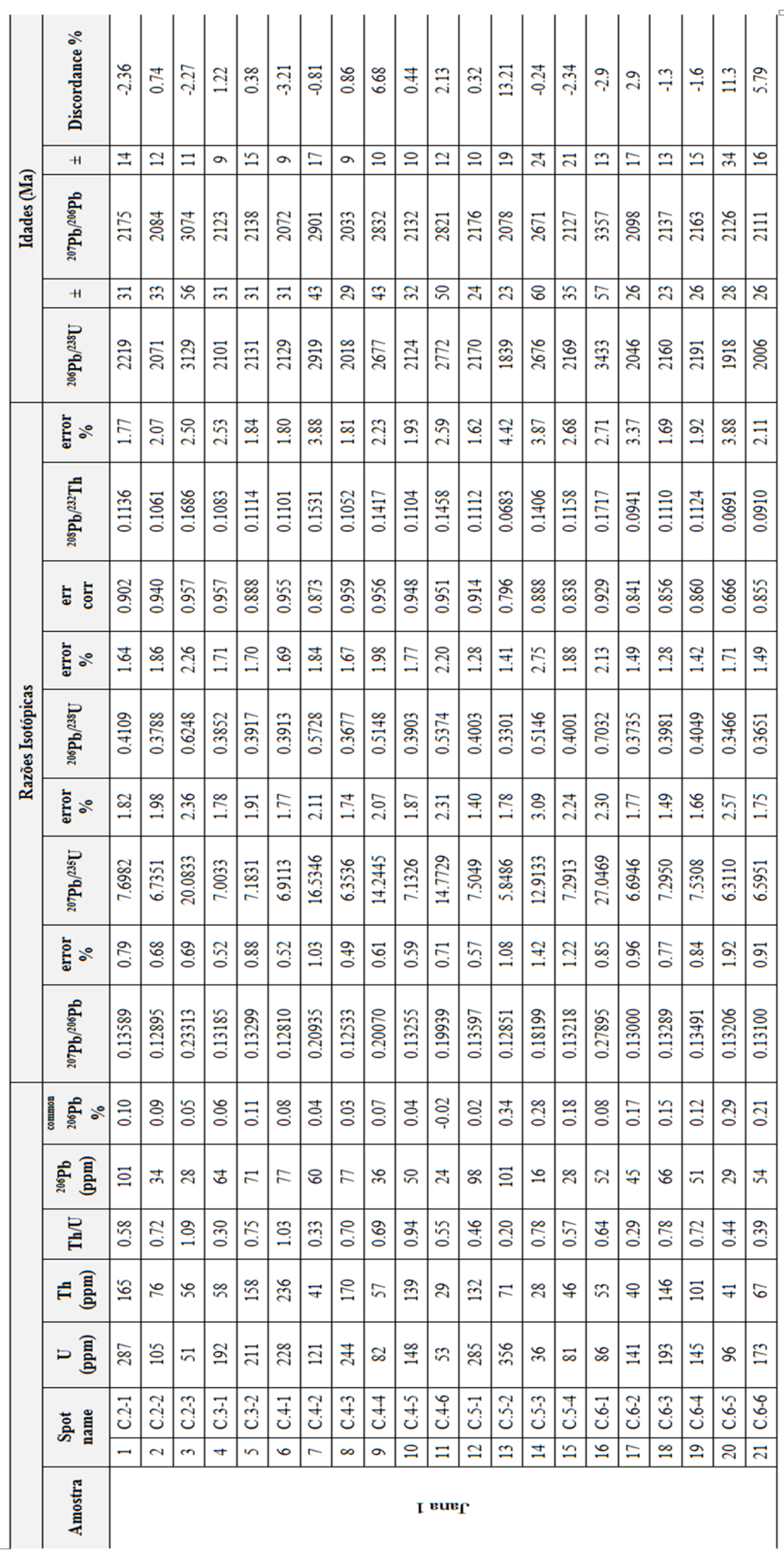


Tabela 2 - Dados analíticos referentes aos estudos isotópicos U-PB em zircões detríticos da amostra Jana 2.

\begin{tabular}{|c|c|c|c|c|c|c|c|c|c|c|c|c|c|c|c|c|c|c|c|c|}
\hline \multirow{5}{*}{ 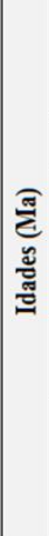 } & 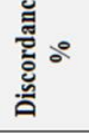 & ले & $\stackrel{\circ}{\circ}$ & $\mid$\begin{tabular}{c}
$\infty$ \\
\hdashline \\
$i$ \\
$i$
\end{tabular} & ت्ञ & $\stackrel{\vec{p}}{\vec{p}}$ & $\stackrel{\stackrel{S}{-}}{-}$ & \begin{tabular}{c}
0 \\
\hdashline \\
\\
\end{tabular} & דִ & $\begin{array}{l}\infty \\
\stackrel{0}{\circ} \\
\rightarrow\end{array}$ & \begin{tabular}{l} 
: \\
\hdashline \\
\hdashline
\end{tabular} & & హీ & & 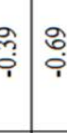 & ho & 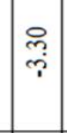 & $\vec{m}$ & $\exists$ & ฮี \\
\hline & H & $\Xi$ & $a$ & 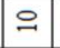 & $r$ & $=$ & ㅇ & $\approx$ & $\Xi$ & $=$ & $\Rightarrow$ & $\cong$ & $\approx 5$ & 97 & $2 \because$ & 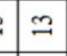 & 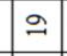 & $\cong$ & $=$ & $\approx$ \\
\hline & 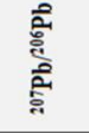 & 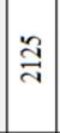 & ్ֶయి & $\stackrel{\tilde{m}}{\vec{\sim}}$ & $\overrightarrow{\vec{c}}$ & $\stackrel{亏}{\beth}$ & สิ & $\overrightarrow{\vec{s}}$ & 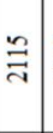 & $\vec{\overrightarrow{ }}$ & $\begin{array}{l}\stackrel{a}{\vec{\Delta}} \\
\vec{\sim}\end{array}$ & : & $\overrightarrow{\text { ते }}$ & 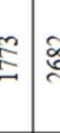 & $\stackrel{\substack{c \\
c}}{2}$ & : & $\overrightarrow{\mathrm{s}}$ & 吕 & $\stackrel{\infty}{\sim}$ & $\stackrel{\circ}{\circ}$ \\
\hline & 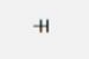 & ले & z & m & $F$ & m & $\vec{m}$ & 覀 & $\approx$ & 焉 & ¿ & 'ร & $\infty$ & 8 & of & 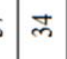 & $\vec{m}$ & F & 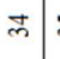 & $\approx$ \\
\hline & 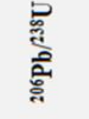 & 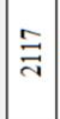 & ळ్యి & $\overrightarrow{\vec{c}}$ & 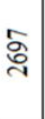 & $\stackrel{\mathbb{2}}{\mathbf{2}}$ & $\stackrel{\Xi}{\vec{\lambda}}$ & $\stackrel{2}{\sim}$ & $\stackrel{\widetilde{m}}{\vec{\sim}}$ & $\overrightarrow{\vec{े}}$ & สิ & 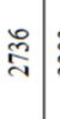 & તิి & $\stackrel{0}{0}$ & : & 点 & $\underset{\stackrel{\Phi}{\triangle}}{\vec{D}}$ & E్ & $\stackrel{8}{-}$ & $\stackrel{\frac{⿱}{\vec{\gamma}}}{\vec{\lambda}}$ \\
\hline \multirow{9}{*}{ 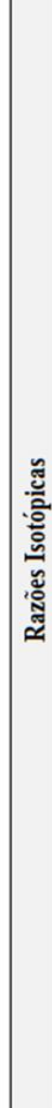 } & 잏ㅇ & 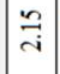 & $\overrightarrow{\mathrm{i}}$ & $\underset{i}{8}$ & $\stackrel{\circ}{\leftrightarrows}$ & के & $\stackrel{\circ}{\mathrm{i}}$ & নี & 空 & $\stackrel{2}{i}$ & $\stackrel{m}{\vec{i}}$ & $\stackrel{7}{m}$ & $\vec{~}$ & $\exists$ & 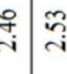 & חี & $\stackrel{2}{\mathrm{i}}$ & $\stackrel{m}{\vec{i}}$ & $\stackrel{\infty}{\mathrm{i}}$ & $\vec{\lambda}$ \\
\hline & 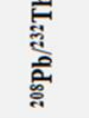 & 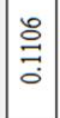 & $\begin{array}{l}\stackrel{8}{+: ~} \\
\stackrel{0}{0}\end{array}$ & 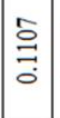 & $\frac{\mathbb{Z}}{\stackrel{\mathcal{Z}}{0}}$ & $\underset{0}{\stackrel{\Xi}{\Xi}}$ & $\begin{array}{c}\stackrel{\Xi}{\Xi} \\
0\end{array}$ & $\begin{array}{l}\stackrel{\Xi}{\exists} \\
\stackrel{0}{0}\end{array}$ & $\begin{array}{l}\text { ㅇ. } \\
\text { : } \\
0\end{array}$ & $\begin{array}{c}\stackrel{0}{0} \\
\stackrel{0}{0} \\
0\end{array}$ & $\begin{array}{c}\infty \\
\stackrel{0}{\exists} \\
0 \\
0\end{array}$ & : & : & & $\begin{array}{l}0 \\
0 \\
0\end{array}$ & $\stackrel{0}{0}$ & $\mid \begin{array}{l}\Xi \\
\delta \\
0 \\
0\end{array}$ & $\mid \begin{array}{c}\tilde{0} \\
\stackrel{0}{0} \\
0\end{array}$ & 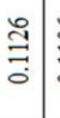 & 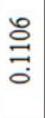 \\
\hline & 5 & 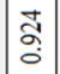 & $\begin{array}{l}\overrightarrow{0} \\
\circ\end{array}$ & స్⿱ & ב̂. & ڤ్. & 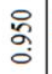 & $\begin{array}{l}\text { 今ै } \\
\text { oี }\end{array}$ & శี & $\begin{array}{l}\text { 志 } \\
\text { Oे }\end{array}$ & $\begin{array}{l}\text { ờ } \\
\text { ơ }\end{array}$ & ๙ે. & ְ: & 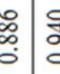 & 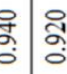 & 冬 & 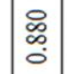 & \begin{tabular}{c|c|} 
on \\
on \\
\end{tabular} & $\begin{array}{l}\text { Jे } \\
0\end{array}$ & ふু \\
\hline & 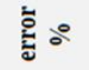 & $\stackrel{\infty}{-\infty}$ & gे & $\stackrel{2}{\leftrightarrows}$ & @ & $\vec{i}$ & $\stackrel{\mathscr{S}}{-}$ & $\stackrel{\leftrightarrow}{-\infty}$ & $\stackrel{\approx}{-}$ & $\begin{array}{l}\stackrel{+}{\Phi} \\
\stackrel{-}{*}\end{array}$ & $\stackrel{8}{9}$ & $\begin{array}{l}\text { ¿े } \\
\text { ¿ }\end{array}$ & $\stackrel{9}{-}$ & $\frac{2}{2}$ & $\begin{array}{c}\infty \\
\text { i }\end{array}$ & $\overbrace{-\rightarrow}^{\infty}$ & 䒯 & $\underset{-}{-}$ & $\stackrel{\leftrightarrow}{-}$ & ดิ \\
\hline & 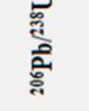 & $\begin{array}{c}\text { ㅇ. } \\
\text { o. } \\
\end{array}$ & 究 & \begin{tabular}{|l}
$\vec{\circ}$ \\
ळे \\
0
\end{tabular} & 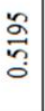 & $\begin{array}{l}\hat{\delta} \\
⿱ 亠 䒑 \\
0 \\
0\end{array}$ & 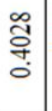 & $\begin{array}{c}\vec{\sigma} \\
\text { రై }\end{array}$ & 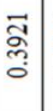 & $\begin{array}{l}\text { o } \\
\text { ơ⿱ } \\
0 \\
0\end{array}$ & $\underset{\stackrel{\Xi}{*}}{\stackrel{\Xi}{*}}$ & 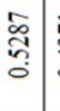 & $\begin{array}{c}\overrightarrow{7} \\
0 \\
0\end{array}$ & & 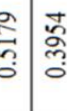 & 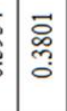 & $\begin{array}{l}\text { శี } \\
\text { హె }\end{array}$ & 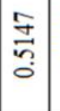 & $\begin{array}{l}\overrightarrow{0} \\
\text { o } \\
0\end{array}$ & ণ্ \\
\hline & 。ํㅎㅇ & §ి & ড્ & $\underset{-}{\stackrel{\sim}{+}}$ & $\stackrel{8}{9}$ & సై & $\vec{a}$ & $\stackrel{1}{\circ}$ & $\stackrel{ }{i}$ & $\stackrel{-g}{g}$ & $\vec{i}$ & $\stackrel{0}{\rightarrow}$ & 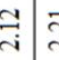 & $\overrightarrow{\bar{c}}$ & ت্ & $\overbrace{i}^{\infty}$ & $\overrightarrow{\mathfrak{A}}$ & $\vec{i}$ & $\stackrel{2}{\Im}$ & ֶ̊ \\
\hline & 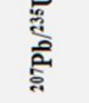 & 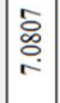 & 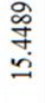 & $\mid \begin{array}{l}n \\
\\
\end{array}$ & 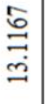 & $\begin{array}{l}\vec{F} \\
\text { à } \\
\end{array}$ & 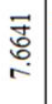 & 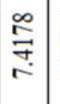 & 兽 & $\begin{array}{l}\text { 总 } \\
\stackrel{2}{\sim}\end{array}$ & $\begin{array}{l}\widetilde{\tilde{\delta}} \\
\stackrel{2}{\sim}\end{array}$ & 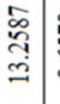 & . & & 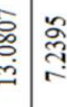 & $\mid \begin{array}{c}0 \\
0 \\
0 \\
0\end{array}$ & 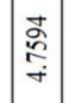 & 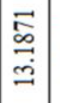 & 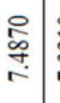 & 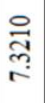 \\
\hline & 열 & $\begin{array}{l}\infty \\
\vdots \\
0 \\
0\end{array}$ & ถి & 号 & 学 & 형 & $\stackrel{8}{\circ}$ & : & \begin{tabular}{c|c|c|}
$\overrightarrow{0}$ \\
0 \\
0
\end{tabular} & $\begin{array}{l}\text { ț } \\
0 \\
0\end{array}$ & : & E. & $\stackrel{2}{c}$ & $\underbrace{1}_{-i}$ & $\begin{array}{l}0 \\
0 \\
0\end{array}$ & $\int_{0}^{a}$ & $\stackrel{\leftrightarrow}{-}$ & $\mid$\begin{tabular}{l}
$\infty$ \\
\hdashline \\
$o$
\end{tabular} & 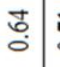 & F \\
\hline & 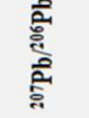 & 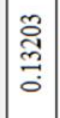 & 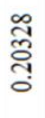 & 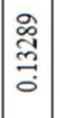 & 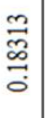 & $\begin{array}{c}\stackrel{0}{m} \\
\stackrel{m}{0} \\
0\end{array}$ & $\begin{array}{c}2 \\
2 \\
0 \\
0 \\
0\end{array}$ & 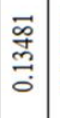 & 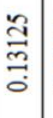 & 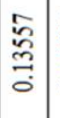 & $\begin{array}{c}\text { 兽 } \\
0 \\
0\end{array}$ & $\begin{array}{c}\infty \\
0 \\
0 \\
0 \\
0\end{array}$ & 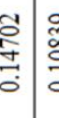 & 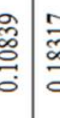 & 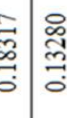 & $\begin{array}{l}2 \\
\text { à } \\
0 \\
0\end{array}$ & $\mid \begin{array}{l}0 \\
\stackrel{0}{0} \\
0 \\
0\end{array}$ & $\mid \begin{array}{c}\tilde{0} \\
\stackrel{0}{0} \\
\stackrel{0}{0}\end{array}$ & 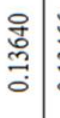 & 㝵 \\
\hline & 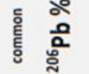 & $\stackrel{\infty}{0}$ & ¿̊̊ & $\stackrel{\circ}{\circ}$ & 范 & 궁 & $\overrightarrow{0}$ & 。̊. & $\stackrel{m}{0}$ & ठ̊. & : & $\stackrel{1}{\circ}$ & : & $\frac{1}{3}$ & $\begin{array}{l}c \\
0 \\
0\end{array}$ & : & $\stackrel{2}{2}$ & : & :̊) & 苂 \\
\hline & 高 & $\tilde{m}$ & లే & $\approx$ & $\vec{F}$ & ¿ి & $\infty$ & $\bar{m}$ & $\stackrel{\infty}{\infty}$ & o & $m$ & $\vec{m}$ & 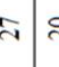 & ¿ิ ઈ & $\pi \mid \tau$ & i & Z & i & $\vec{m}$ & ते \\
\hline & $\bar{F}$ & 綮 & 号 & \begin{tabular}{|l|} 
\\
0 \\
0
\end{tabular} & $\begin{array}{l}\text { : } \\
0 \\
0\end{array}$ & $\begin{array}{l}0 \\
0 \\
0\end{array}$ & 告 & $\begin{array}{ll}\text { t. } \\
\text { of }\end{array}$ & F. & 管 & 党 & : & 家 & : & $\begin{array}{c}\infty \\
0 \\
0\end{array}$ & 筞 & $\underset{-}{\mathcal{Z}}$ & 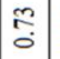 & $\begin{array}{l}\vec{f} \\
0\end{array}$ & ถิ \\
\hline & 表言 & in & $\vec{m}$ & : & $\cong$ & $\vec{\lambda}$ & in & $\infty$ & $\vec{m}$ & in & $\therefore$ & $\infty$ & 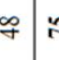 & $=$ & $F \quad \vec{N}$ & $F$ & $\Xi$ & 8 & $F$ & $\stackrel{\infty}{+}$ \\
\hline & $=$ 畜 & \$ & $\mathscr{\circ}$ & $\cong$ & $\cong$ & $\stackrel{\infty}{\infty}$ & $\Xi$ & 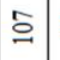 & ఉ & $\cong$ & ¿ & $\mathscr{\circ}$ & $\dot{*}$ & $5 \%$ & $g$ & $\sigma$ & $\infty$ & $\infty$ & $\approx$ & ळ) \\
\hline & \multirow{2}{*}{ के 흠 } & $\overrightarrow{\overrightarrow{\vec{I}}}$ & 竞 & $\begin{array}{l}\overrightarrow{\vec{j}} \\
\vec{\omega}\end{array}$ & تُ & $\begin{array}{c}3 \\
\vec{u} \\
\tilde{u}\end{array}$ & 菅 & $\begin{array}{c}\vec{m} \\
\dot{\omega}\end{array}$ & 今. & $\begin{array}{c}\vec{f} \\
\dot{w} \\
\dot{y}\end{array}$ & $\begin{array}{c}\mathcal{F} \\
\dot{w}\end{array}$ & 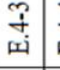 & $\begin{array}{l}f \\
\dot{m}\end{array}$ & $\begin{array}{l}\overrightarrow{0} \\
\dot{\omega}\end{array}$ & 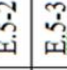 & 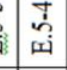 & 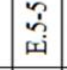 & 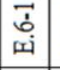 & 它 & $\overrightarrow{\dot{D}}$ \\
\hline & & (ี) & ก & A & 2 & $\stackrel{i}{ }$ & 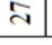 & $\begin{array}{l}\infty \\
\mathbf{c}\end{array}$ & ते| & i & $\vec{m}$ & లి| & $\stackrel{m}{\bar{c}}$ & $\begin{array}{c}\mathrm{m} \\
\mathrm{m}\end{array}$ & $\therefore$ & $\tilde{m}$ & $\left|\begin{array}{c}\infty \\
m\end{array}\right|$ & ले & & $F$ \\
\hline & 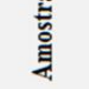 & & & & & & & & & & & & & & & & & & & \\
\hline
\end{tabular}


Tabela 3 - Dados analíticos referentes aos estudos isotópicos U-PB em zircões detríticos da amostra Jana 3.

\begin{tabular}{|c|c|c|c|c|c|c|c|c|c|c|c|c|c|c|c|c|c|c|c|c|}
\hline \multirow{5}{*}{ 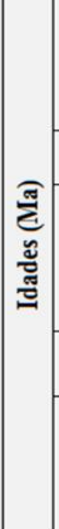 } & 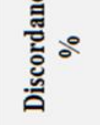 & $\stackrel{\overbrace{}}{\rightarrow}$ & $\underset{-}{F}$ & $\vec{E}$ & 它 & ్ㅗ & $\stackrel{5}{-}$ & $\stackrel{7}{7}$ & $\stackrel{g}{\rightarrow}$ & 号 & $\stackrel{\dddot{m}}{\rightarrow}$ & $\begin{array}{l}n \\
\dot{r} \\
\dot{r}\end{array}$ & $\begin{array}{l}\tilde{0} \\
\stackrel{?}{\circ}\end{array}$ & $\mid \begin{array}{l}1 \\
\vdots \\
i \\
i\end{array}$ & 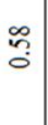 & $\begin{array}{l}\text { ळ. } \\
\grave{i}\end{array}$ & $\stackrel{\overbrace{}}{\rightarrow}$ & $\overrightarrow{\grave{i}}$ & $\underset{\oplus}{\stackrel{m}{-}}$ & శ్ \\
\hline & $H$ & $\approx$ & 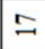 & ले & 은 & $\Xi$ & $\simeq$ & 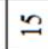 & $\simeq$ & 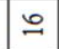 & $\cong$ & $\bar{\approx}$ & ส & $\simeq$ & $\simeq$ & $\approx$ & \pm & $\Rightarrow$ & $\Rightarrow$ & $m$ \\
\hline & 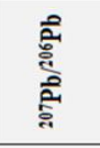 & $\stackrel{\tilde{m}}{\vec{n}}$ & $\stackrel{\dddot{े}}{\vec{\sim}}$ & సี & సి & $\frac{9}{4}$ & 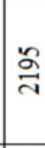 & 兽 & à & 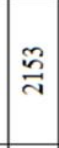 & 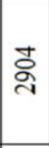 & 亏े & $\overrightarrow{\vec{a}}$ & $\exists$ & 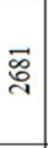 & ते & పి & $\frac{\hat{m}}{\vec{\sim}}$ & ڤ̊̀ & $\vec{\Xi}$ \\
\hline & H & $\approx$ & m) & mे & $\approx$ & ল্ & ల & $\tilde{m}$ & $F$ & ని & in & $\stackrel{i}{ }$ & $\vec{m}$ & A & 岕 & m & $\vec{\sigma}$ & ले & a & F \\
\hline & 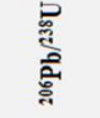 & $\stackrel{\circ}{\stackrel{2}{*}}$ & 웜 & $\stackrel{2}{\frac{\partial}{2}}$ & 원 & $\stackrel{\infty}{\stackrel{\infty}{\sim}}$ & $\stackrel{\text { สิ }}{2}$ & : & 今్ & 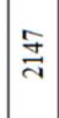 & 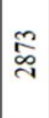 & 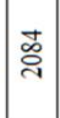 & $\begin{array}{c}\bar{\infty} \\
\vec{\sim}\end{array}$ & $\exists$ & : & $\frac{0}{2}$ & 여 & $\overrightarrow{\vec{a}}$ & 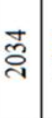 & 웜 \\
\hline \multirow{9}{*}{ 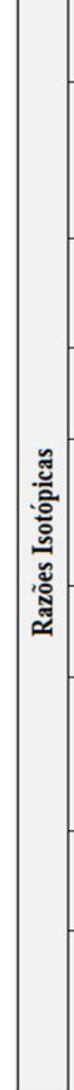 } & 홍 & $\underset{ت}{ت}$ & ते & กิ & 党 & $\stackrel{\text { i }}{\mathrm{i}}$ & i & 誉 & $\stackrel{\overbrace{}}{~}$ & 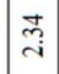 & $\stackrel{\varpi}{\stackrel{\aleph}{i}}$ & $\stackrel{\substack{\infty \\
\rightarrow}}{\rightarrow}$ & $\stackrel{i}{i}$ & $\overrightarrow{\stackrel{\sigma}{-}}$ & $\stackrel{9}{-}$ & तี & ל̊. & 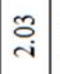 & $\stackrel{\overbrace{}}{-}$ & $\stackrel{\bullet}{\circ}$ \\
\hline & 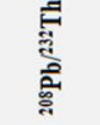 & $\begin{array}{l}\text { 蒿 } \\
\text { : }\end{array}$ & 总 & 窝 & 呑 & $\underset{0}{\stackrel{9}{*}}$ & 学 & $\stackrel{\mathscr{0}}{\stackrel{2}{二}}$ & 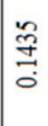 & 楉 & 总 & $\begin{array}{l}0 \\
0 \\
0 \\
0\end{array}$ & $\stackrel{\infty}{\Xi}$ & $\frac{8}{\circ}$ & $\begin{array}{l}\stackrel{2}{2} \\
\stackrel{0}{0} \\
0\end{array}$ & 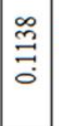 & $\begin{array}{l}\stackrel{\infty}{\circ} \\
\stackrel{0}{0}\end{array}$ & $\begin{array}{c}\tilde{m} \\
\stackrel{3}{0} \\
0\end{array}$ & : & $\stackrel{\text { }}{\stackrel{\mathrm{g}}{0}}$ \\
\hline & $\mathrm{t}$ & 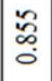 & 。․ & 厄ี & Ŝ & वे & 尔 & హิ & $\begin{array}{l}\overrightarrow{0} \\
\infty \\
\infty \\
0\end{array}$ & \begin{tabular}{|l|}
0 \\
0 \\
0 \\
0
\end{tabular} & హิ & $\mid \begin{array}{l}\infty \\
0 \\
0 \\
0\end{array}$ & ఏ్టి & 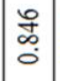 & 今. & $\vec{~} \overrightarrow{0}$ & 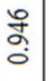 & Fे & $\begin{array}{c}0 \\
0 \\
0 \\
0 \\
0\end{array}$ & $\begin{array}{l}\stackrel{+}{\infty} \\
\stackrel{0}{0}\end{array}$ \\
\hline & 密。웅 & ঙ્ণ & $\stackrel{\text { in }}{\mathrm{i}}$ & 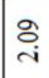 & $\stackrel{\infty}{i}$ & 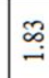 & 옥 & 억 & $\stackrel{\infty}{\leftrightharpoons}$ & $\sqrt{3}$ & $\stackrel{2}{i}$ & 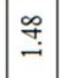 & $\stackrel{\sigma}{-}$ & $\stackrel{\vec{m}}{-}$ & $\sqrt[5]{-1}$ & $\stackrel{\infty}{-}$ & $\stackrel{\infty}{i}$ & $\vec{\infty}$ & $\exists$ & กั \\
\hline & 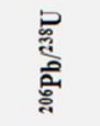 & 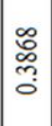 & 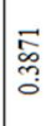 & 突 & 总 & 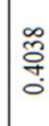 & 㚔 & ळু & 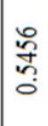 & ఋి & $\begin{array}{l}\frac{T}{0} \\
\text { مू } \\
0\end{array}$ & $\begin{array}{l}0 \\
0 \\
0 \\
0 \\
0 \\
0\end{array}$ & \begin{tabular}{l}
$\infty$ \\
\hdashline \\
$\dot{o}$ \\
0 \\
0
\end{tabular} & $\begin{array}{l}0 \\
\infty \\
0 \\
0 \\
0\end{array}$ & 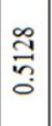 & $\mid \begin{array}{l}0 \\
\text { Oें } \\
0 \\
0\end{array}$ & $\begin{array}{l}\text { 今े } \\
\text { مै } \\
\text {. }\end{array}$ & $\mid \begin{array}{l}0 \\
0 \\
0 \\
0 \\
0\end{array}$ & 俤 & $\begin{array}{l}\text { ò } \\
\text { +े }\end{array}$ \\
\hline & 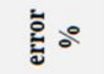 & f & 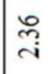 & $\stackrel{\sim}{\infty}$ & กิ & 억 & $\vec{i}$ & 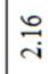 & తి & $\stackrel{\vec{\Phi}}{\rightarrow}$ & 离 & $\underset{\mathrm{i}}{\mathrm{i}}$ & సి & 乌ి & $\underset{I}{\stackrel{T}{Z}}$ & $\stackrel{\varrho}{\Im}$ & $\underset{\mathrm{i}}{\mathrm{i}}$ & 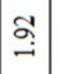 & 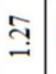 & ભે \\
\hline & 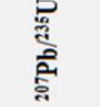 & 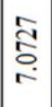 & 第 & 宓 & $\begin{array}{l}\infty \\
\stackrel{\infty}{m} \\
\end{array}$ & 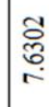 & 홍 & 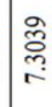 & 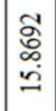 & 总 & $\mid \begin{array}{l}\hat{\tilde{z}} \\
\tilde{s} \\
\underline{G}\end{array}$ & \begin{tabular}{|l|l} 
\\
0 \\
0 \\
0 \\
0
\end{tabular} & 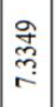 & 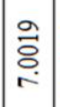 & $\begin{array}{l}\text { वे } \\
\text { वे. } \\
\text { తi }\end{array}$ & 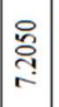 & 先 & 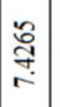 & 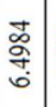 & 文 \\
\hline & 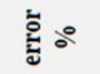 & : & 영 & $\stackrel{+}{-}$ & 웅 & : & $\stackrel{5}{\circ}$ & 志 & 志 & Sీ & $\vec{a}$ & કี & $\stackrel{\overbrace{}}{\Im}$ & $\stackrel{\leftrightarrow}{\infty}$ & $\frac{\pi}{0}$ & : & \begin{tabular}{c}
$\infty$ \\
$\infty$ \\
\hdashline
\end{tabular} & : & ¿্ర: & ठ্ণ \\
\hline & 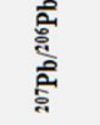 & $\begin{array}{l}\overrightarrow{0} \\
\text { ज. } \\
\overrightarrow{0}\end{array}$ & $\begin{array}{l}\infty \\
\stackrel{-}{7} \\
0 \\
0\end{array}$ & 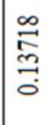 & 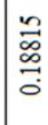 & $\begin{array}{l}\text { ò } \\
\text { on } \\
0\end{array}$ & 胥 & 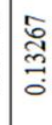 & 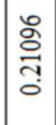 & $\underset{\substack{7 \\
0 \\
0}}{\stackrel{7}{7}}$ & 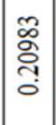 & 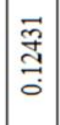 & 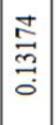 & $\mid \begin{array}{c}\overrightarrow{0} \\
\stackrel{0}{0} \\
0\end{array}$ & $\begin{array}{l}\stackrel{m}{\vec{\infty}} \\
\stackrel{\infty}{-} \\
\stackrel{0}{0}\end{array}$ & $\begin{array}{l}\overrightarrow{\widetilde{n}} \\
\stackrel{-}{0}\end{array}$ & 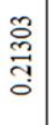 & $\mid \begin{array}{l}\stackrel{2}{0} \\
\stackrel{0}{0} \\
\stackrel{0}{0}\end{array}$ & 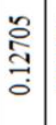 & 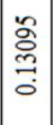 \\
\hline & 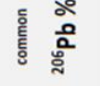 & $\stackrel{m}{0}$ & $\stackrel{0}{\circ}$ & ?7 & $\stackrel{0}{0}$ & Oे & 웅. & $\stackrel{\infty}{\circ}$ & $\stackrel{0}{0}$ & $\stackrel{0}{0}$ & \begin{tabular}{|l|}
0 \\
0 \\
$i$ \\
$i$
\end{tabular} & \begin{tabular}{l|}
0 \\
0 \\
0
\end{tabular} & สี & 7 & $\stackrel{0}{0}$ & 号 & 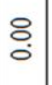 & oे & $\overrightarrow{0}$ & 응 \\
\hline & 言言 & 3 & 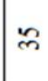 & $F$ & 8 & \% & if & m & $\stackrel{\infty}{+}$ & లి & $\stackrel{\sim}{\infty}$ & ; & $\vec{m}$ & 䓃 & $\therefore$ & 7 & 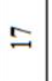 & 웅 & $\vec{\infty}$ & \pm \\
\hline & $\stackrel{?}{\sharp}$ & gे & î̀ & $\stackrel{\infty}{0}$ & $\vec{\circ}$ & $\stackrel{\infty}{0}$ & 형 & $\stackrel{\substack{0 \\
0}}{0}$ & గ̂̀ & 昰 & 孪 & 点 & 芯 & $\vec{n}$ & $\underset{-}{\stackrel{\infty}{-}}$ & 悉 & $\exists$ & $\begin{array}{l}\overrightarrow{0} \\
\dot{0} \\
0\end{array}$ & ڤ̆ & ले \\
\hline & $\approx$ 高 & d & in & $\because$ & $\bar{\infty}$ & 8 & $\Xi$ & m & $\therefore$ & లి & $\infty$ & 2 & ৪্ল & $\ddot{\infty}$ & ટ્વે & 요 & ले & $\infty$ & శ్ & $\stackrel{\circ}{\circ}$ \\
\hline & $D$ 言 & ప & 흠 & $\stackrel{\infty}{=}$ & 寻 & 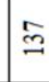 & శ్ & $\infty$ & $\cong$ & $\cong$ & $\stackrel{\infty}{n}$ & $\hat{m}$ & வ & $\stackrel{0}{\circ}$ & $\Xi$ & $\stackrel{\infty}{\dddot{\sim}}$ & m & $\cong$ & ๙ิ & 웅 \\
\hline & \multirow{2}{*}{$\begin{array}{l}\text { 离 } \\
\text { 행 } \\
\text { की }\end{array}$} & $\vec{I}$ & $\frac{3}{4}$ & $\frac{3}{4}$ & $\overrightarrow{\dot{3}}$ & $\tilde{Z}$ & $\frac{\tilde{3}}{4}$ & 竡 & $\overrightarrow{\dot{m}}$ & 官 & $\vec{m}$ & $\vec{z}$ & $\underset{f}{\mathcal{Y}}$ & $\mid \begin{array}{l}3 \\
\dot{q} \\
\dot{4}\end{array}$ & 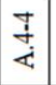 & $\mid \overrightarrow{\dot{b}}$ & 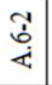 & $\begin{array}{l}3 \\
\dot{b} \\
\dot{4}\end{array}$ & $\begin{array}{l}\overrightarrow{0} \\
\dot{q}\end{array}$ & Sُ \\
\hline & & 7 & F & F & 17 & 8 & 7 & कo & 9 & 8 & $\vec{n}$ & กี & $\approx$ & मे & $\therefore$ & י & $\therefore$ & \begin{tabular}{|l|}
$\infty$ \\
$\infty$
\end{tabular} & 8. & 8 \\
\hline
\end{tabular}


Tabela 4 - Dados analíticos referentes aos estudos isotópicos U-PB em zircões detríticos da amostra Jana 5.

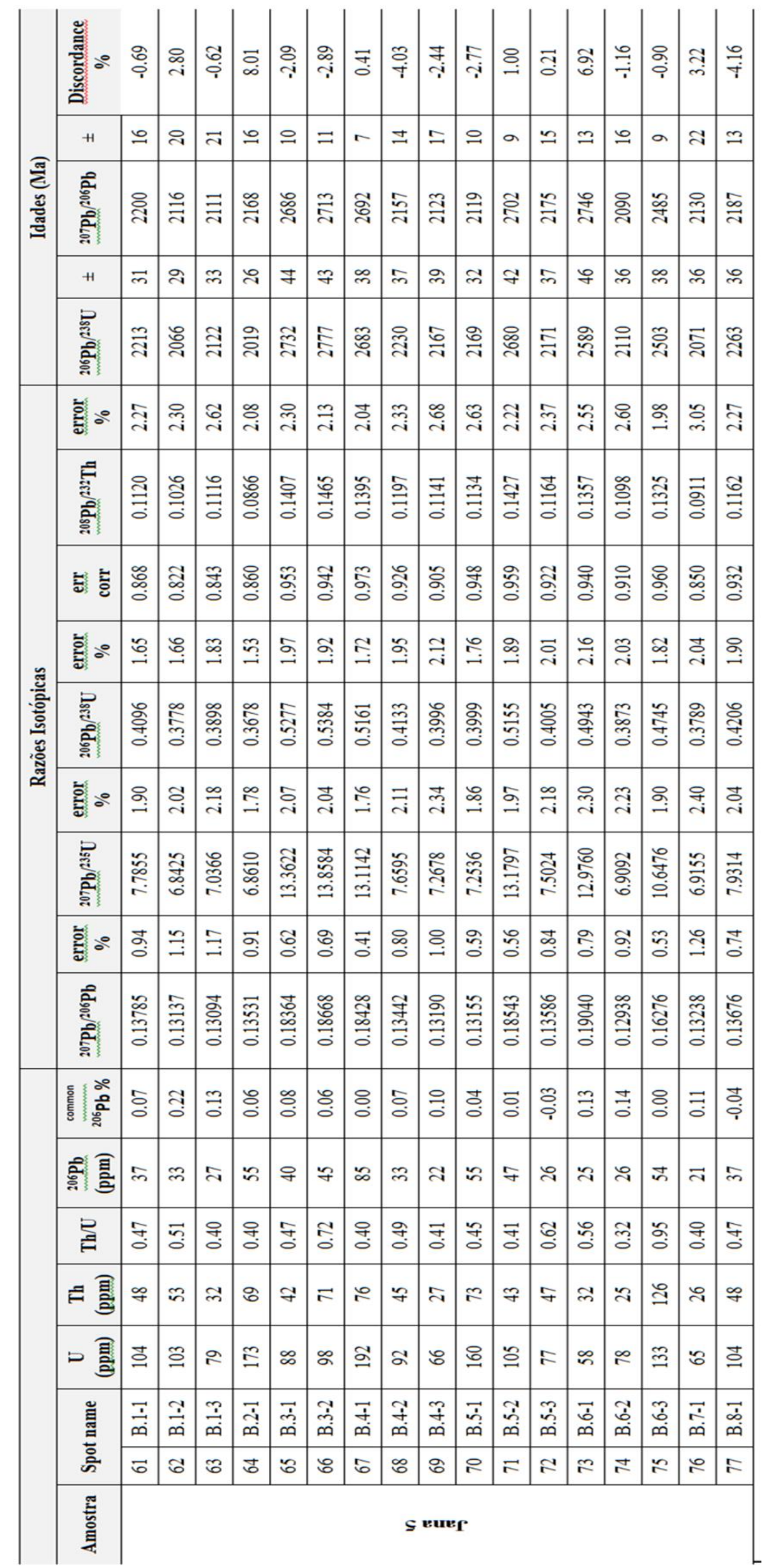


Rochas do Mesoarqueano estão representadas pelos granitos do Complexo Gouveia com idade de cristalização em zircão de $2.839 \pm 14 \mathrm{Ma}$ e metarriolitos pertencentes ao Grupo Pedro Pereira (Supergupo Rio Paraúna) com idade de $2.971 \pm 16 \mathrm{Ma}$ (Machado et al., 1989). Estas rochas afloram na região central da bacia, a norte da área estudada. Nas regiões de Altamira e Ipoema afloram gnaisses do Complexo Belo Horizonte com idade de U-Pb, em zircões de um mobilizado migmatítico, de $2.860+14 /-10 \mathrm{Ma}$ (Noce, 1995), considerada como a idade de migmatização dos gnaisses do Complexo Belo Horizonte. É provável, que todas estas rochas serviram como fonte dos zircões com estas idades.

O Neoarqueano também não possui registro nos domínios da Serra do Espinhaço Meridional, porém, ocorrem intrusões de granitoides potássicos com idades entre 2.750 Ma e 2.600 Ma (Romano et al., 2013) nas rochas mesoarqueanas do Complexo Belo Horizonte. As intrusões conhecidas e cartografadas estão localizadas a oeste e a sul da área estudada. Além disso, afloram a leste da serra, gnaisses TTG do Complexo Guanhães com idade de $2.711 \mathrm{Ma}$ (Noce et al., 2007a, b).

As rochas do Complexo Guanhães dificilmente contribuíram como fonte dos zircões com estas idades, levando em consideração sua posição geográfica a leste e as paleocorrentes na bacia espinhaço em seu setor meridional. Os granitoides potássicos podem ser uma provável fonte destes zircões devido à posição geográfica de alguns corpos a oeste, e devido ao fato de serem rochas intrusivas no Complexo Belo Horizonte, unidade aflorante nas regiões de Altamira e Ipoema e denominada neste trabalho de Embasamento Gnáissico-migmatítico.

O Sideriano também não possui registro nos domínios da Serra do Espinhaço Meridional, entretanto, dois zircões apresentaram idades referentes a esta era geológica com $2.311 \pm 13$ Ma (amostra Jana 2, spot E.4-4) e $2.485 \pm 9 \mathrm{Ma}$ (amostra Jana 5, spot B.6-3). Estas idades podem ser encontradas em rochas graníticas do Cinturão Mineiro (Barbosa et al., 2013) que está localizado a SSW da área estudada. Entretanto, os dados de paleocorrentes não colaboram com uma associação destas rochas à fonte destes zircões, deixando uma lacuna em relação à sua possível fonte, havendo a necessidade de estudos mais detalhados que ajudem a elucidar esta questão.

O Riaciano/Orosiriano está representado por metarriolitos do Grupo Costa Sena (Supergrupo Rio Paraúna) com idade de $2.049 \pm 16 \mathrm{Ma}$ em zircão (Machado et al., 1989). Estas rochas também afloram na porção central da bacia, a norte da área estudada e podem ser consideradas como as rochas fonte dos zircões que apresentaram idades deste período do tempo geológico.

Em relação ao Estateriano, está representado pelos granitos da Suíte Borrachudos com idade de cristalização em zircão de $1.770 \pm 30 \mathrm{Ma}$ (Fernandes et al., 2000), metarriolitos da Suíte Conceição do Mato Dentro com idades de 1.770 Ma (Brito Neves et al., 1979) e $1.711 \pm 8 \mathrm{Ma}$ (Machado et al., 1989) e filitos hematíticos, rochas de protólito ígneo (Knauer \& Schrank, 1994) que ocorrem em meio às rochas metassedimentares da Formação São João da Chapada e possuem idade $\mathrm{Pb}-\mathrm{Pb}$ de $1.770 \pm 12$ Ma (Dossin et al. 1993).

As suítes Borrachudos e Conceição do Mato Dentro afloram na borda leste da Serra do Espinhaço Meridional, enquanto os filitos hematíticos afloram na porção central da bacia nas proximidades da cidade de Diamantina. Levando em consideração as paleocorrentes que são de oeste para leste e de norte para sul, as duas suítes não poderiam ter contribuído com o aporte sedimentar da bacia devido à sua posição geográfica, sendo os filitos hematíticos a provável fonte dos zircões desta idade.

Comparando os dados geocronológicos/ litológicos apresentados neste trabalho com os de outros trabalhos já realizados nas unidades basais do Supergrupo Espinhaço (formações Bandeirinha, São João da Chapada e Sopa-Brumadinho) na porção central da bacia (Dossin et al. 1993, Chemale Jr. et al., 2012; Santos et al. 2013), admite-se que a Unidade Basal pode ser correlacionada com a Formação Bandeirinha e/ou São João da Chapada (Figura 21). Comparando com dados geocronológicos/ litológicos de outros trabalhos já realizados em rochas metassedimentares basais da borda leste do Espinhaço (Rolim et al., 2016; Silveira, 2016) admite-se que a Unidade Basal pode ser correlacionada com a Formação Lapão (Figura 21).

$\mathrm{Na}$ tentativa de uma correlação mais ampla, uma comparação das associações litológicas e suas características da região de Altamira e Ipoema, com as associações litológicas e suas características, conhecidas na porção central, 
leva à uma correlação das unidades Intermediária e Superior com as formações Sopa-Brumadinho e Galho do Miguel respectivamente, e comparando com as associações litológicas e suas características, conhecidas na borda leste, podemos correlacionar a Unidade Intermediária à Formação Itapanhoacanga (Figura 21).
A correlação da Unidade Basal com as formações descritas na porção central e na borda leste tem maior robustez devido à utilização de dados isotópicos e litológicos, porém, a correlação das outras duas unidades é frágil, existindo a necessidade de outros dados que corroborem estas correlações.

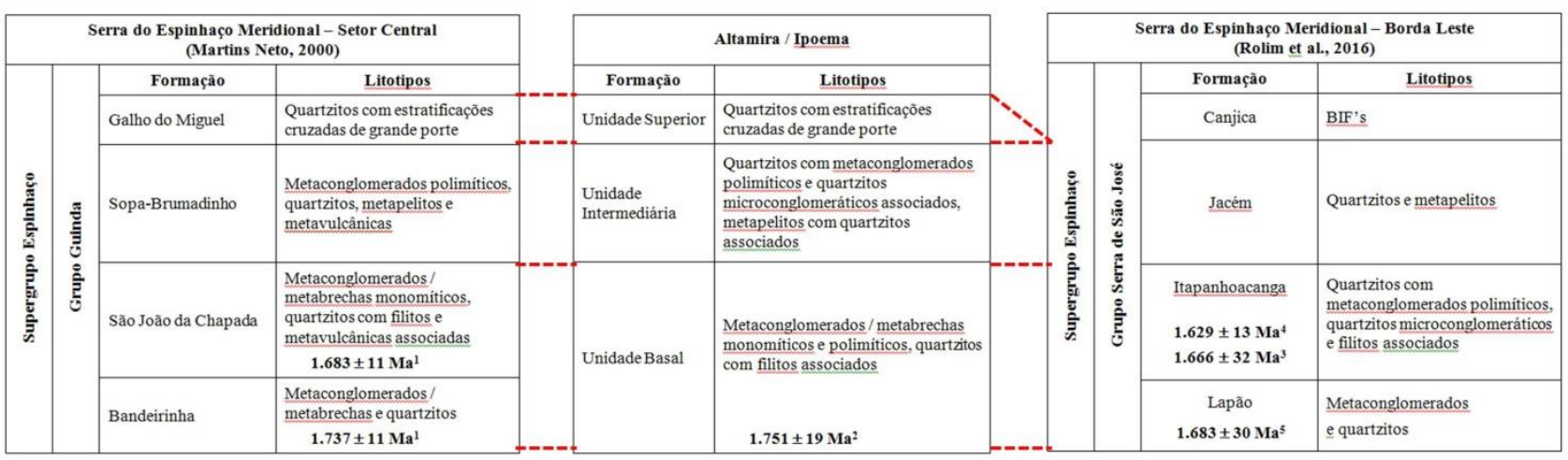

Figura 21 - Correlações estratigráficas das unidades basais do Supergrupo Espinhaço no setor meridional, na porção central (Martins-Neto, 2000), borda leste (Rolim et al., 2016) e região de Altamira/Ipoema. Idades geocronológicas: (1) Chemale Jr. et al. (2012); (2). Este trabalho; (3) Rolim et al. (2016); (4 e 5) Silveira (2016).

\section{CONCLUSÕES}

A unidade metassedimentar basal definida neste trabalho está sobreposta diretamente a um embasamento gnáissico-migmatítico arqueano de idade aproximada de $2,8 \mathrm{Ga}$ que pode ser correlacionado ao Complexo Belo Horizonte. O contato entre estas duas unidades possui caráter tectônico. Esta unidade metassedimentar basal marca o início do registro sedimentar nas regiões de Altamira e Ipoema e foi informalmente nomeada de Unidade Basal, podendo ser correlacionada às formações Bandeirinha/São João da Chapada (porção central) e à Formação Lapão (borda leste) pertencentes ao Supergrupo Espinhaço. A Unidade Basal tem como característica marcante, metaconglomerados/ metabrechas polimíticos na base da sequência, que estão sobrepostos por quartzitos que os recobrem por completo. Os resultados dos estudos geocronológicos realizados nestes quartzitos permitem atribuir a esta unidade uma idade máxima de deposição de $1.751 \pm 19 \mathrm{Ma}(>95 \%$ concordância), indicando que o processo de sedimentação nas regiões de Altamira e Ipoema, iniciou ao final do Paleoproterozoico no período Estateriano $(1,8-1,6 \mathrm{Ga})$.

A distribuição dos picos de idade no histograma sugere que o preenchimento da bacia nas regiões de Altamira e Ipoema ocorreu por aporte de fontes mais antigas localizadas a oeste e norte da bacia, com predomínio de sedimentos autóctones oriundos em sua maioria de terrenos de idade riaciana/orosiriana, representados nos domínios da Serra do Espinhaço Meridional pelas rochas do Grupo Costa Sena, unidade de topo do Supergrupo Rio Paraúna, com idade aproximada de $2.05 \mathrm{Ga}$, seguidos por sedimentos com fonte em terrenos mesoarqueanos/ neoarqueanos representados pelo Grupo Pedro Pereira, unidade basal do Supergrupo Rio Paraúna, com idade aproximada de 3,0 Ga, os complexos Belo Horizonte e Gouveia com idade aproximada de $2,85 \mathrm{Ga}$, granitoides potássicos intrusivos no Complexo Belo Horizonte com idades no intervalo de 2,75 - 2,60 Ga, além de sedimentos relacionados a rochas do período estateriano, associados aos filitos hematíticos de idade $1,77 \mathrm{Ga}$, que afloram na porção central da bacia Espinhaço nos arredores de Diamantina. Ocorreu uma pequena contribuição sedimentar alóctone representada por zircões de terrenos de idade sideriana e paleoarqueana. A fonte de idade sideriana precisa ser melhor investigada devido ao fato de que as rochas desta idade, mais próximas (Cinturão Mineiro) da região estudada, estão em uma posição geográfica que, de acordo com os dados de paleocorrentes da Serra do Espinhaço Meridional, não poderiam ter sido fonte de sedimentos para a bacia.

Os inéditos dados geocronológicos obtidos nas regiões de Altamira e Ipoema e apresentados neste trabalho estão longe de encerrar a questão de qual unidade geológica marca o início da 
sedimentação na bacia Espinhaço no seu setor elucidação destas questões, contribuindo com meridional e qual sua idade, mas contribuem de informações geológicas referentes ao forma significativa na evolução da busca pela Supergrupo Espinhaço até então inexistentes.

\section{AGRADECIMENTOS}

Os autores agradecem à equipe do LAPEGE/UNESP - Rio Claro em especial ao professor Peter Hackspacher por gentilmente permitir o uso das instalações do laboratório para a preparação física das amostras, à Dra. Lucília Ramos e ao pesquisador João Batista, ambos do CDTN/UFMG, ao professor Joachim Karfunkel do CPMTC/IGC/UFMG pelo fornecimento de bibliografias e companherismo em campo e aos professores Atlas Vasconcelos Corrêa Neto (UFRJ) e Lúcio Mauro Soares Fraga (UFVJM) pelas valiosas contribuições geológicas.

\section{REFERÊNCIAS}

ALKMIM, F.F.; MARSHAK, S.; PEDROSA-SOARES, A.C.; PERES, G.G.; CRUZ, S.C.P.; WHITTINGTON, A. Kinematic evolution of the Araçuaí-West Congo Orogen in Brazil and Africa: nutcracker tectonics during the neoproterozoic assembly of Gondwana. Precambrian Research, v.149, p. 4364, 2006.

ALMEIDA-ABREU, P.A. A evolução geodinâmica da Serra do Espinhaço Meridional, Minas Gerais, Brasil. Freiburg, 1993, 150 p. Tese (Doutorado em Geociências) - AlbertLudwigs-Universität Freiburg.

ALMEIDA-ABREU, P.A.; KNAUER, L.G.; HARTMANN, M.B.; SANTOS, G.G.V.; GUIMARÃES, M.V.L.; ABREU, F.R.; SCHRANK, A.; PFLUG, R. Estratigrafia, faciologia e tectônica do Supergrupo Espinhaço na região de Serro-Conceição do Mato Dentro, Minas Gerais, Brasil. Zentralblatt für Geologie und Paläontologie, Teil I, p. 857-853, 1989.

ALMEIDA-ABREU, P.A. \& PFLUG, R. The geodynamic evolution of the southern Serra do Espinhaço, Minas Gerais, Brazil. Zentralblatt für Geologie und Paläontologie, Teil I, p. 21-44, 1994.

ALMEIDA-ABREU, P. A. \& RENGER F. E. Serra do Espinhaço Meridional: um orógeno de colisão do Mesoproterozóico. Revista Brasileira de Geociências, v. 32, n. 1, p. 1-14, 2002.

BARBOSA, J.S.F. \& SABATÉ, P. Archean and Paleoproterozoic crust of the São Francisco Craton, Bahia, Brazil: geodynamic features. Precambrian Research, v. 133, p. 1-27, 2004.

BARBOSA, N.; TEIXEIRA, W.; ÁVILA, C.A.; BONGIOLO, E.M.; DUSSIN, I.A. Ortognaisses siderianos (2450 a $2410 \mathrm{Ma})$ na parte sul do cráton do São Francisco: geocronologia e significado para o cinturão Mineiro. In: Congresso Brasileiro de Geoquímica, 14, 2013, Diamantina. Boletim de Resumos Expandidos, Diamantina, 2013, p. 4.

BRANDALISE, L.A. \& HEINECK, C.A. CPRM COMPANHIA DE PESQUISA DE RECURSOS MINERAIS - SERVIÇO GEOLÓGICO DO BRASIL. Belo Horizonte projeto de mapeamento geológico/metalogenético sistemático da folha SE.23-Z-C-VI (Belo Horizonte), Estado de Minas Gerais, Escala 1:100.000. Belo Horizonte: Programa Levantamentos Geológicos Básicos do Brasil / Companhia de Pesquisa de Recursos Minerais - Serviço Geológico do Brasil - Superintendência Regional de Belo Horizonte, 190 p., 1999.

BRITO NEVES, B.B.; CORDANI, U.G.; KAWASHITA, K.; DELHAL, J. A Evolução geocronológica da Cordilheira do Espinhaço - Dados novos e Integração. Revista Brasileira de Geociências, v. 9, n. 1, p. 71-85, 1979.

CHEMALE, Jr. F.; DUSSIN, I.A.; ALKMIM, F.F.; MARTINS, M.S.; QUEIROGA, G.; ARMSTRONG, R.; SANTOS, M.N. Unravelling a proterozoic basin history through detrital zircon geochronology: The case of the Espinhaço Supergroup, Minas Gerais, Brazil. Gondwana Research, v. 22, p. 200-206, 2012.

DANDERFER, A.; DE WAELE, B.; PEDREIRA, A.J.; NALINI, A.H. New geochronological constraints on the geological evolution of the Espinhaço basin within the São Francisco
Craton - Brazil. Precambrian Research, v. 170, p.116-128, 2009.

DOSSIN, I.A. \& DARDENNE, M.A. Geologia da borda ocidental da Serra do Cipó, Minas Gerais. In: CONGRESSO BRASILEIRO DE GEOLOGIA, 33, 1984. Rio de Janeiro. Anais... Rio de Janeiro: Sociedade Brasileira de Geologia, 1984, v. 3, p. 3104-3117.

DOSSIN, I.A.; CHAVES, M.L. DE S.C.; UHLEIN, A.; ALVARENGA, C.J. DE S. Geologia e depósitos diamantíferos da região de Sopa, Diamantina, MG. In: SIMPÓSIO DE GEOLOGIA DE MINAS GERAIS, 5, 1985, Belo Horizonte. Anais... Belo Horizonte: Sociedade Brasileira de Geologia, 1985, p. 276-290.

DOSSIN, I.A.; DOSSIN, T.M.; CHARVET, J.; COCHERIE, A.; ROSSI, P. Single-zircon dating by step-wise Pb-evaporation of Middle Proterozoic magmatismo in the Espinhaço range, southeastern São Francisco Craton, Minas Gerais, Brazil. In: SIMPÓSIO SOBRE O CRÁTON DO SÃO FRANCISCO, 2 , 1993, Salvador. Anais.... Salvador: sociedade Brasileira de Geologia, 1993.

FERNANDES, M.I.S.; PEDROSA-SOARES, A.C.; NOCE C.M.; WIEDEMAN, C.; CORREIA NEVES, J.M. U-Pb Geochronology of the Borrachudos Suite: Evidence of Brasiliano Tectonism Recorded by Late Paleoproterozoic Anorogenic Granites (Araçuaí Belt, Minas Gerais, Brazil). In: International Geological Congress, 2000, Rio de Janeiro. Abstracts Volume, CD. Rio de Janeiro, 2000.

FOGAÇA A.C.C., ALMEIDA-ABREU P.A. \& SCHORSCHER H.D. Estratigrafia da sequência supracrustal arqueana na porção mediana central da Serra do Espinhaço, MG. In: CONGRESSO BRASILEIRO DE GEOLOGIA, 33, 1984. Anais...Rio de Janeiro: Sociedade Brasileira de Geologia, 1984, 2652- 2667.

KNAUER, L.G. Evolução geológica do Pré-cambriano da porção centro leste da Serra do Espinhaço Meridional e metalogênese associada. Campinas, 1990. 298p. Dissertação (Mestrado em Geociências) - Instituto de Geociências, Universidade Estadual de Campinas.

KNAUER, L.G. O Supergrupo Espinhaço em Minas Gerais: Considerações sobre a sua estratigrafia e seu arranjo estrutural. Geonomos, v. 15, n. 1, p. 81-90, 2007.

KNAUER, L.G. \& SCHRANK, A. A origem dos filitos hematíticos da Serra do Espinhaço Meridional, Minas Gerais. Geonomos, v. 1, n. 1, p. 33-38, 1994.

KNAUER, L. G. \& Grossi-Sad, J. H. COMIG - COMPANHIA MINERADORA DE MINAS GERAIS. Belo Horizonte Geologia da Folha Serro (SE-23-Z-B-IV), Estado de Minas Gerais, Escala 1:100.000. Belo Horizonte: Projeto Espinhaço em CD-ROM (textos e mapas), 263 p., 1995.

LUDWIG, K.R. User's manual for ISOPLOT/Ex 3.00. A geochronological toolkit for Microsoft Excel. Berkeley Geochronological Center Special Publication 4, 70 p, Version 3.00, Berkeley, 2003.

LUDWIG, K. SQUID 2: A User's Manual. Berkeley Geochronological Center Special Publication 5, 110 p, 
Version 2.50, Berkeley, 2009.

MACHADO, N.; SCHRANK, A.; ABREU, F.R.; KNAUER, L.G.; ALMEIDA-ABREU, P.A. 1989. Resultados preliminares da geocronologia U/Pb na Serra do Espinhaço Meridional. In SIMPÓSIO DE GEOLOGIA DE MINAS GERAIS, 10, 1989, Belo Horizonte. Anais... Belo Horizonte: Sociedade Brasileira de Geologia, 1989, p. 171-174.

MARTINS-NETO, M.A. O Supergrupo Espinhaço em Minas Gerais: registro de uma bacia rift-sag do Paleo/Mesoproterozoico. Revista Brasileira de Geociências, v. 28, n. 2 , p.151-168, 1998 .

MARTINS-NETO, M.A. Tectonics and sedimentation in a paleo/mesoproterozoic rift-sag basin (Espinhaço Basin, southeastearn Brazil). Precambrian Research, n. 103, p.147$173,2000$.

NOCE, C.M. Geocronologia dos eventos magmáticos, sedimentares e metamórficos na região do Quadrilátero Ferrífero, Minas Gerais. São Paulo, 1995, 128 p. Tese (Doutorado em Geoquímica e Geotectônica) - Instituto de Geociências, Universidade de São Paulo.

NOCE, C.M.; PEDROSA-SOARES, A.C.; SILVA, L.C.; ARMSTRONG, R.; PIUZANA, D. Evolution of polycyclic basement complexes in the Araçuaí Orogen, based on $\mathrm{U}-\mathrm{Pb}$ SHRIMP data: Implications for Brazil-Africa links in Paleoproterozoic time. Precambrian Research, n. 159, p. 6078, 2007a.

NOCE, C.M.; PEDROSA-SOARES, A.C.; SILVA, L.C.; ALKMIM, F.F. O embasamento Arqueano e Paleoproterozóico do orógeno Araçuaí. Geonomos, v. 15, n. 1, p. 17-23, 2007b.

PADILHA, A.V.; VIEIRA, V.S.; HEINECK, C.A. CPRM COMPANHIA DE PESQUISA DE RECURSOS MINERAIS - SERVIÇO GEOLÓGICO DO BRASIL. Belo Horizonte projeto de mapeamento geológico/metalogenético sistemático da folha SE.23-Z-D-IV (Itabira), Estado de Minas Gerais, Escala 1:100.000. Belo Horizonte: Programa Levantamentos Geológicos Básicos do Brasil / Companhia de Pesquisa de Recursos Minerais - Serviço Geológico do Brasil - Superintendência Regional de Belo Horizonte, 71 p., 2000.

PEDROSA-SOARES, A.C.; NOCE, C.M.; WIEDEMANN, C.; PINTO, C.P. The Araçuaí-West Congo Orogen in Brazil: an overview of a confined orogen formed during Gondwanaland Assembly. Precambrian Research, n. 110, p. 307-323, 2001. PEDROSA-SOARES, A.C.; ALKMIM, F.F.; TACK, L.; NOCE, C.M.; BABINSKI, M.; SILVA, L.C.; MARTINS-NETO, M.A. Similarities and differences between the Brazilian and African counterparts of the Neoproterozoic Araçuaí-West-Congo orogen. Geological Society, London, Special Publications, v. 294, p.153-172, 2008.

PFLUG, R. Observações sobre a estratigrafia da Série Minas na região de Diamantina, Minas Gerais. Rio de Janeiro: Departamento Nacional de Produção Mineral/Divisão Geologia e Mineração, Boletim, v. 142, 20 p, 1968.

RODRIGUES DA SILVA, M.C. A Formação SopaBrumadinho nos campos diamantíferos de São João da Chapada, Sopa-Guinda e Extração, Diamantina - Minas Gerais: Sistemas Deposicionais, Tratos de Sistemas, geoquímica e geocronologia urânio-chumbo e lutécioháfnio. Belo Horizonte, 2016, 330 p. Tese (Doutorado em
Geologia) - Instituto de Geociências, Universidade Federal de Minas Gerais.

ROLIM, V.K. Uma interpretação das estruturas tectônicas do Supergrupo Espinhaço, baseado na geometria dos falhamentos de empurrão. Revista da Escola de Minas, v. 45, n. 1 e 2, p. 75-77, 1992

ROLIM, V.K; ROSIÈRE, C.A.; SANTOS, J.O.S.; MCNAUGHTON, N.J. The Orosirian-Statherian banded iron formation-bearing sequences of the southern border of the Espinhaço Range, Southeast Brazil. Journal of South American Earth Sciences, v. 65, p. 43-66, 2016.

ROMANO, R.; LANA, C.; ALKMIM, F.F.; STEVENS, G.; ARMSTRONG, R. Stabilization of the southern portion of the São Francisco Craton, SE Brazil, through a long-lived period of potassic magmatism. Precambrian Research, v. 224, p. 143159,2013

SANTOS, M.N.; CHEMALE, Jr. F.; DUSSIN I.A.; MARTINS, M.; ASSIS, T.A.R.; JELINEK, A.R.; GUADAGNIN, F.; ARMSTRONG, R. Sedimentological and paleoenvironmental constraints of the Statherian and Stenian Espinhaço rift system, Brazil. Sedimentary Geology, v. 290, p.47-59, 2013.

SCHÖLL, W.U. \& FOGAÇA, A.C.C. Estratigrafia da Serra do Espinhaço na região de Diamantina. In: SIMPÓSIO DE GEOLOGIA DE MINAS GERAIS, 1, Diamantina, 1979. Atas...Diamantina: Sociedade Brasileira de Geologia, 1979, p. 55-73.

SILVA, R.R. As Bacias Proterozoicas do Espinhaço e São Francisco em Minas Gerais: uma abordagem sob o ponto de vista da estratigrafia de sequências. Geonomos, v. 6, n.1, p. 112,1998

SILVA, R.R. O sistema de cavalgamentos do tipo duplex neoproterozoico da Serra do Espinhaço, Minas Gerais. Revista Brasileira de Geociências, v. 41, n. 2, p. 157-169, 2011.

SILVEIRA, V.D. Geologia e Geocronologia da Região de Serro, Serra do Espinhaço Meridional, Minas Gerais, Brasil. Belo Horizonte, 2016. 45 p. Dissertação (Mestrado em Geologia) - Instituto de Geociências, Universidade Federal de Minas Gerais.

SPERBER, M. Von. Geologie des Präkambriums am Südwestrand der Serra do Cipó (Serra do Espinhaço, Minas Gerais, Brasilien). Hannover, 1977, 55 p. Tese (Doutorado em Geociências).

UHLEIN, A. Geologia e mineralogia da cromita e itabiritos da região do Serro MG. Brasília, 1982. 192 p. Dissertação (Mestrado em Geociências) - Instituto de Geociências, Universidade de Brasília.

UHLEIN, A.; TROMPETTE, R.; SILVA, M.E. Estruturação tectônica do Supergrupo Espinhaço na região de Diamantina, Minas Gerais. Revista Brasileira de Geociências, v. 16, n. 2, p. 212-216, 1986 